United States Department of Interior

Geological Survey

\title{
SEDIMENTATION AND TECTONICS OF THE SYLHET TROUGH, NORTHEASTERN BANGLADESH
}

by

Samuel Y. Johnson

U.S. Geological Survey, MS 939

Box 25046, DFC

Denver, CO 80225

and

Abu Md. Nur Alam

Geological Survey of Bangladesh

Segun Bagicha

Dhaka - 1000, Bangladesh

Open File Report 90-313

This report is preliminary and has not been edited or reviewed for conformity with Geological Survey editorial standards and stratigraphic nomenclature 


\begin{abstract}
The Sylhet trough of northeastern Bangladesh is a tectonically complex province of the Bengal Basin bounded by the Indian Shield, the Shillong Plateau, and the ChittagongTripura fold belt of the Indo-Burman ranges. This trough contains a thick fill $(12-16 \mathrm{~km})$ of late Mesozoic and Cenozoic strata that record its tectonic evolution. This report describes stratigraphic, sedimentologic, and petrographic data collected from outcrops, cores, well logs, and seismic lines. We use these data to reconstruct basin history.

The pre-Oligocene history of the Bengal Basin was characterized by sedimentation on a passive continental margin associated with Mesozoic rifting and opening of the Indian Ocean. The Sylhet trough likely occupied a transitional setting on this margin between shelf deposits to the northwest and basinal deposits to the southeast. Subsidence may have increased slightly during the Oligocene in response to crustal loading from the developing Indo-Burman ranges. Oligocene strata (Barail Formation) exposed on the northern margin of the Sylhet trough are fluvial, but probably grade basinward (to the southeast) over a short distance into a deltaic and prodeltaic deposits. Barail Formation strata were probably derived from incipient uplifts in the Himalayas.

Subsidence rates increased in the Miocene, probably in response to encroachment of the west-advancing Indo-Burman ranges. Miocene to earliest Pliocene sediments of the Surma Group were deposited in a large river-, wave- and tide(?)-influenced delta system that may have drained a significant proportion of the eastern Himalayas.

Subsidence rates increased dramatically (3-8 times) from the Miocene to the Pliocene and Pleistocene in the Sylhet trough, when the Tipam Sandstone and the Dupi Tila Formation were being deposited in bed-load and mixed-load river systems, respectively. This dramatic subsidence and facies change is attributed mainly to south-directed overthrusting of the Shillong Plateau on the Dauki fault for the following reasons: 1) Pliocene and Pleistocene strata thin markedly away from the Shillong Plateau, consistent with a crustal load emplaced on the northern basin margin. 2) The Shillong Plateau is draped by Mesozoic to Miocene rocks, but Pliocene strata are not represented, suggesting the massif was an uplifted block at this time. 3) South-directed overthrusting of the Shillong Plateau is consistent with gravity data and with recent seismotectonic observations. Sandstones in the Tipam show a marked increase in sedimentary lithic fragments compared to older rocks, mainly attributable to uplift and erosion of the sedimentary cover of the Shillong Plateau. If the Dauki fault has a dip similar to that of other Himalayan thrust faults, then a few tens of $\mathrm{km}$ of horizontal tectonic transport would be required to carry the Shillong Plateau to its present elevation. Uplift of the Shillong Plateau probably generated a major (about $300 \mathrm{~km}$ ) westward shift in the course of the Brahmaputra River.
\end{abstract}

\title{
INTRODUCTION
}

The Sylhet trough of northeastern Bangladesh is a tectonically complex province of the Bengal Basin (figs. 1,2). The Sylhet trough is bounded on the north by the Shillong Plateau, on the east and southeast by the Tripura-Chittagong fold belt, and on the west by the Indian Shield platform; the trough is.open to the southwest and south to the main part of the Bengal Basin. Previously published estimates of the thickness of late Mesozoic and Cenozoic strata in the Sylhet trough range from about 13 to $17 \mathrm{~km}$ (Evans, 1964; Hiller and Elahi, 1984), and much of this strata is Neogene in age. The Sylhet trough has minimal topographic relief and is actively subsiding. Although many workers have reported on the geology and hydrocarbon potential of the Sylhet trough (for example, Holtrop and Keizer, 1970; Lietz and Kabir, 1982; Hiller and Elahi, 1984, Khan and others, 1988), detailed sedimentologic and petrologic studies of its sedimentary fill are lacking. This lack of data largely reflects two factors: 1) Outcrops are generally of poor quality and occur only on the 


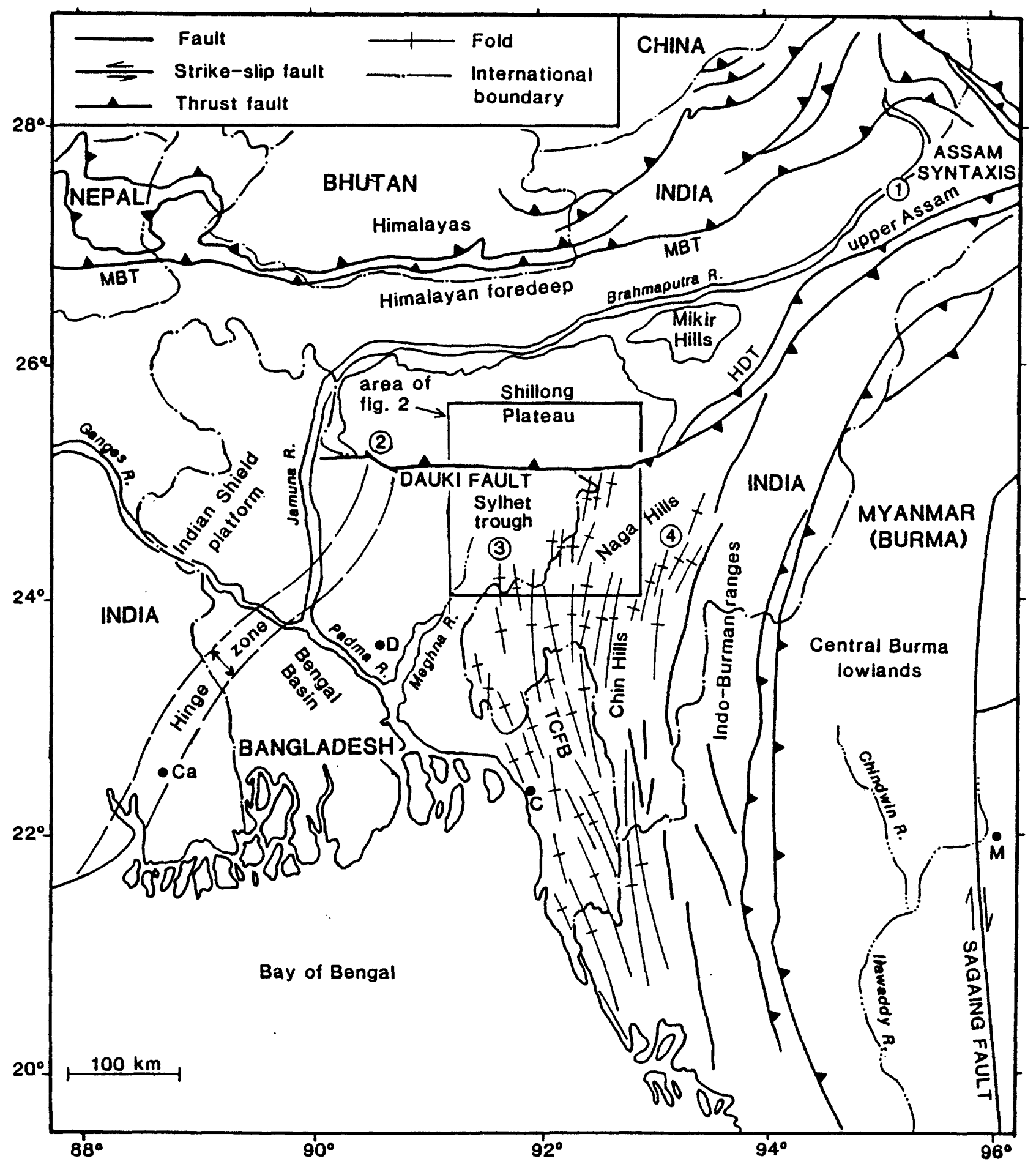

Figure 1. Schematic map showing the location of the Sylhet trough and surrounding tectonic elements. Abbreviations: $C=$ Chittagong; $\mathrm{Ca}=\mathrm{Calcutta} ; \mathrm{D}=\mathrm{Dhaka} ; \mathrm{HDT}=$ Haflong-Disang thrust system; $M$ = Mandalaya; $M B T=$ Main Boundary thrust fault; TCFB $=$ Tripura-Chittagong fold belt. Circled numbers show the approximate locations of the composite stratigraphic columns shown in Figure 4. Based on Ray (1982), Acharya and others (1986), and Salt and others (1986). 


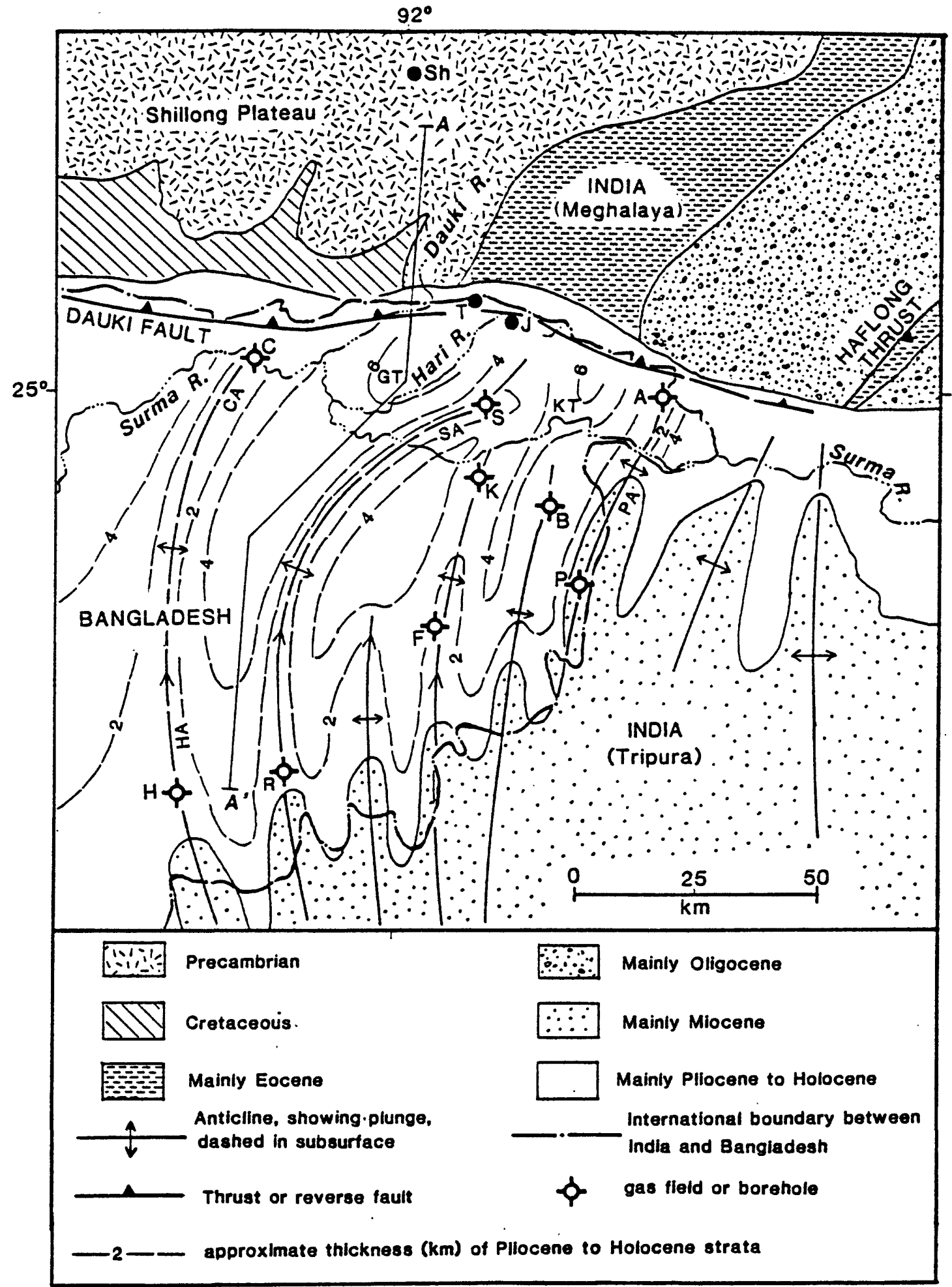

Figure 2. Schematic geologic map of the Sylhet trough, northeastem Bangladesh (location shown on fig. 1). Abbreviations as follows: $\mathrm{A}=$ Atgram borehole; $\mathrm{B}=\mathrm{Beani}$ Bazar gas field; $C=$ Chhatak gas field; $C A=$ Chhatak anticline; $F=$ Fenchuganj borehole; $G T=$ Goyain trough; $\mathrm{H}=$ Habiganj gas field; $\mathrm{HA}=$ Habiganj anticline; $\mathrm{J}=\mathrm{Jaintiapur}, \mathrm{K}=\mathrm{Kailas}$ Tila gas field; $K T=$ Kushiara trough; $P=$ Patharia borehole; $P A=$ Patharia anticline; $R=$ Rasidpur gas field; $\mathrm{S}=$ Sylhet gas field; $\mathrm{SA}=$ Sylhet anticline; $\mathrm{Sh}=$ Shillong; $\mathrm{T}=$ Tama Bil. See figure 4, column 3, for Sylhet trough stratigraphic units. Isopach of Pliocene to Holocene strata is approximate and is based on limited well and seismic data, and the interpretations of Lietz and Kabir (1982) and Hiller and Elahi (1984). A-A' is line of section for figure 9 . 
uplifted, densely vegetated, basin margins. 2) The Sylhet trough is a frontier petroleum province that has not been extensively drilled and, therefore, only limited core is available for study. Our data on outcrop and core studies of Neogene and Oligocene strata address this deficiency. These data, and observations based on examination of well logs and seismic data, allow reconstruction of the sedimentary and tectonic evolution of the Sylhet trough. We propose that the Sylhet trough evolved from 1) a passive continental margin (pre-Oligocene), to 2) a foreland basin linked to the encroaching Indo-Burman ranges (Oligocene and Miocene), to 3) a foreland basin linked to south-directed overthrusting of the Shillong Plateau (Pliocene to Holocene).

\section{GEOLOGIC SETTING}

The Cretaceous to Holocene Bengal Basin, underlying the deltaic portions of Bangladesh and adjacent India, and the Bay of Bengal (fig. 1), forms a "remnant ocean basin" (Mitchell and Reading, 1986) at the juncture of the Indian plate and the Burma microplate or platelet (Curray and others, 1983). Basin development began in the Late Cretaceous (about $127 \mathrm{Ma}$ ) when the Indian plate was rifted away from Antarctica along an inferred northeast-southwest trending ridge system. After a plate reorganization at about 90 $\mathrm{Ma}$, the Indian plate began migrating rapidly northward, leading to its collision with Asia, initiated during the Eocene between about 55 and $40 \mathrm{Ma}$ (Curray and others, 1983; Molnar, 1984). Major uplift of the Himalayas may not have begun until the Miocene (Gansser, 1964).

The western part of the onshore Bengal Basin has been divided into platform or shelf, slope or "hinge", and basinal facies (for example, Evans, 1964; Salt and others, 1986). Crystalline basement of the Indian plate underlies the platform and bounds the Bengal Basin to the west and north; the deeper basin to the east and southeast may be floored by oceanic or transitional crust (Desikachar, 1974; Curray and others, 1983). Paleocene and Eocene strata include carbonate platform and clastic shelf deposits of the Jaintia Group and their thicker basinal correlatives, the Disang Group (fig. 4)). The basin has been characterized by deltaic sedimentation since the Oligocene. Today, the onshore portion of the Bengal Basin is the site of the world's largest delta (about $60,000 \mathrm{~km}^{2}$ ) formed by rivers (Ganges, Brahmaputra/Jamuna, Padma, Meghna) that drain a large proportion of the Himalayas. This subaerial delta feeds the the world's largest submarine fan complex (Bengal Fan), which extends more than $3,000 \mathrm{~km}$ south into the Bay of Bengal (Curray and Moore, 1974).

The Bengal Basin gradually is being encroached on by the Indo-Burman ranges, a roughly $230-\mathrm{km}$-wide, active orogenic belt associated with eastward subduction of the Indian plate below Myanmar (Burma) (Brunnschweiler, 1966; LeDain and others, 1984; Sengupta and others, 1990). Folds and thrust faults in the Indo-Burman ranges trend north-south (fig. 1), consistent with this eastward subduction. Howevr, earthquake data (Ni and others, 1989; Chen and Molnar, in press) show that basement of the Indian plate below the Indo-Burman ranges is moving north. Thus the compressional deformation in the overlying rocks is at least partly decoupled from the basement. Because of this apparent decoupling, the Indo-Burman ranges have been termed the Burma microplate or platelet (Curray and others, 1983). Most of the northward motion of the Indian plate relative to Asia is taken up east of the Indo-Burman ranges on the right-lateral Sagaing fault (fig. 1). At their northernmost extension, the Indo-Burman ranges merge with the westtrending Himalayas in a complex structural zone, the Assam syntaxis. The Main Boundary thrust fault, initiated in latest Miocene or Pliocene (LeFort, 1975), is regarded as the present thrust front of the Himalayas and forms the northern margin of the Himalayan foredeep. This foredeep is relatively narrow in this area and is bounded to the south and separated from the Bengal Basin by the Shillong Plateau. 


\section{THE SYLHET TROUGH}

The Sylhet trough is a sub-basin of the Bengal Basin in northeastern Bangladesh (figs. 1,2 ), and is characterized by a large, closed, negative gravity anomaly (as low as -84 milligals). The Sylhet trough has minimal topography (elevations of less than 5 to $20 \mathrm{~m}$ ), is characterized by numerous lakes and swamps, and is actively subsiding. Estimates of the sediment thickness of the Sylhet trough range from about 13 to $17 \mathrm{~km}$ (Evans, 1964; Hiller and Elahi, 1984). The eastern part of the Sylhet trough lies in the frontal zone of the IndoBurman ranges orogenic belt. North-trending folds that are uplifted in the TripuraChittagong fold belt plunge northward into the Sylhet trough subsurface (figs. 1-3). The anticlines (for example, fig. 3) are commonly faulted, and many produce gas. These folds involve Pliocene and Pleistocene deposits (dipping as steeply as $60^{\circ}$ or more) and are either presently active or have stopped growing recently. Structural relief between paired anticlinal crests and adjacent synclinal troughs may be as much as $7000 \mathrm{~m}$ (Hiller and Elahi, 1984), and the synclines have acted as major late Neogene and Quaternary depocenters. The folds decrease in amplitude westward and are not present west of about $91^{\circ}$ (Lietz and Kabir, 1982), where the Sylhet trough merges with the main part of the Bengal Basin.

The Sylhet trough is bounded to the north by the Shillong Plateau (figs. 1, 2), which is underlain by a basement complex of Archean gneisse and minor greenstone and Late Proterozoic (750 Ma) granite (Acharya and others, 1986). Late Mesozoic and Cenozoic sedimentary cover drapes portions of the southern Shillong Plateau and generally dips south in a monocline (Evans, 1964). The Shillong Plateau has an average elevation of about $1000 \mathrm{~m}$ and a maximum elevation of about $2000 \mathrm{~m}$. Thus, it has been postulated that there may be as much as $15-19 \mathrm{~km}$ of structural relief between the Shillong Plateau and the basement of the Sylhet trough (Hiller and Elahi, 1984). This structural relief is characterized by a steep gravity gradient, about 94 milligals in $40 \mathrm{~km}$ (Rahman and others, 1990).

The poorly exposed Dauki fault (figs. 1,2) forms the contact between the Shillong Plateau and the Sylhet trough. The fault has a nearly straight trace across essentially flat topography. The $5-\mathrm{km}$-wide fault zone is characterized by extensive fracturing (Evans, 1964) and near-vertical (as steep as $85^{\circ}$ ) dips of Pliocene and Pleistocene strata (Khan, 1978). Within about $40 \mathrm{~km}$ south of the Dauki fault, the north-trending folds in the subsurface of the Sylhet trough are upwarped and deflected to a northeast trend.

Evans (1964) proposed about $250 \mathrm{~km}$ of right-lateral displacement on the Dauki fault, envisioning the Shillong Plateau as a displaced spur of the Indian plate. He based this model on local juxtaposition of disparate stratigraphic sequences and correlative Eocene shelf (Sylhet Limestone) and basin (Disang Group) deposits (fig. 4), and on greater inferred amounts of shortening in the Indo-Burman ranges north of the latitude of the Dauki fault than to the south. Subsequently, several workers (Desikachar, 1974; Dasgupta, 1977; Brunnschweiler and Khan, 1978; Rangorao, 1983) disputed the rationale for large lateral displacements and instead emphasized inferred large vertical displacements. Recently Seeber and Armbruster (1981) and Molnar (1987) suggested that the Sylhet trough and its basement are underthrusting the Shillong Plateau and that rupture on this thrust zone produced the great (magnitude $\geq 8$ ) 1897 Assam earthquake, a model consistent with the post-earthquake observations of Oldham (1899). Support for underthrusting comes from interpretation of gravity anomalies (Nandy, 1986; Verna and Kumar, 1987; Chen and Molnar, in press). The elevation of the Shillong Plateau should be compensated by a thick crustal root and yield a negative gravity anomaly of about -100 milligals, not a positive anomaly as noted. Instead, the Shillong Plateau seems to be supported by a strong lithosphere, as would be the case if the Indian plate were thrust below it (Chen and Molnar, in press). The thrust-fault hypothesis for the southern margin of the Shillong Plateau and 


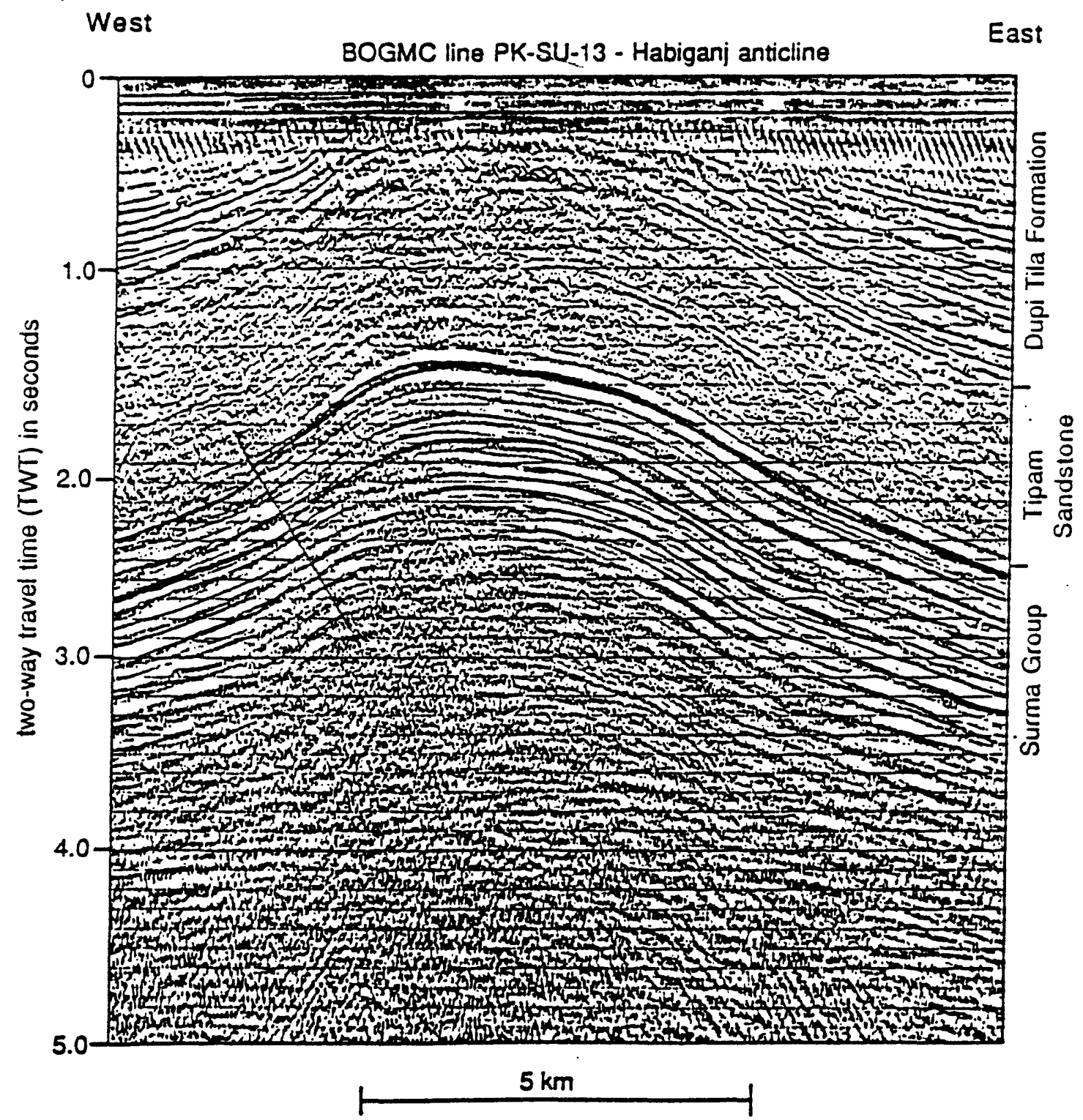

Figure 3. Portion of BOGMC seismic line PK-SU-13 across the Habiganj anticline near the Habiganj gas field (fig. 2), showing the structural style and reflector characteristics of the Surma Group, the Tipam Sandstone, and the Dupi Tila Formation. The Tipam Sandstone thins from about $1500 \mathrm{~m}$ on the east flank of the fold (1.65 to $2.5 \mathrm{sec}$. TWT) to about $1125 \mathrm{~m}(0.65$ to $1.4 \mathrm{sec}$. TWT) over the crest of the fold. The increase in seismic velocity with depth makes this thinning appear less pronounced than described. Note reverse fault on west limb of fold. 


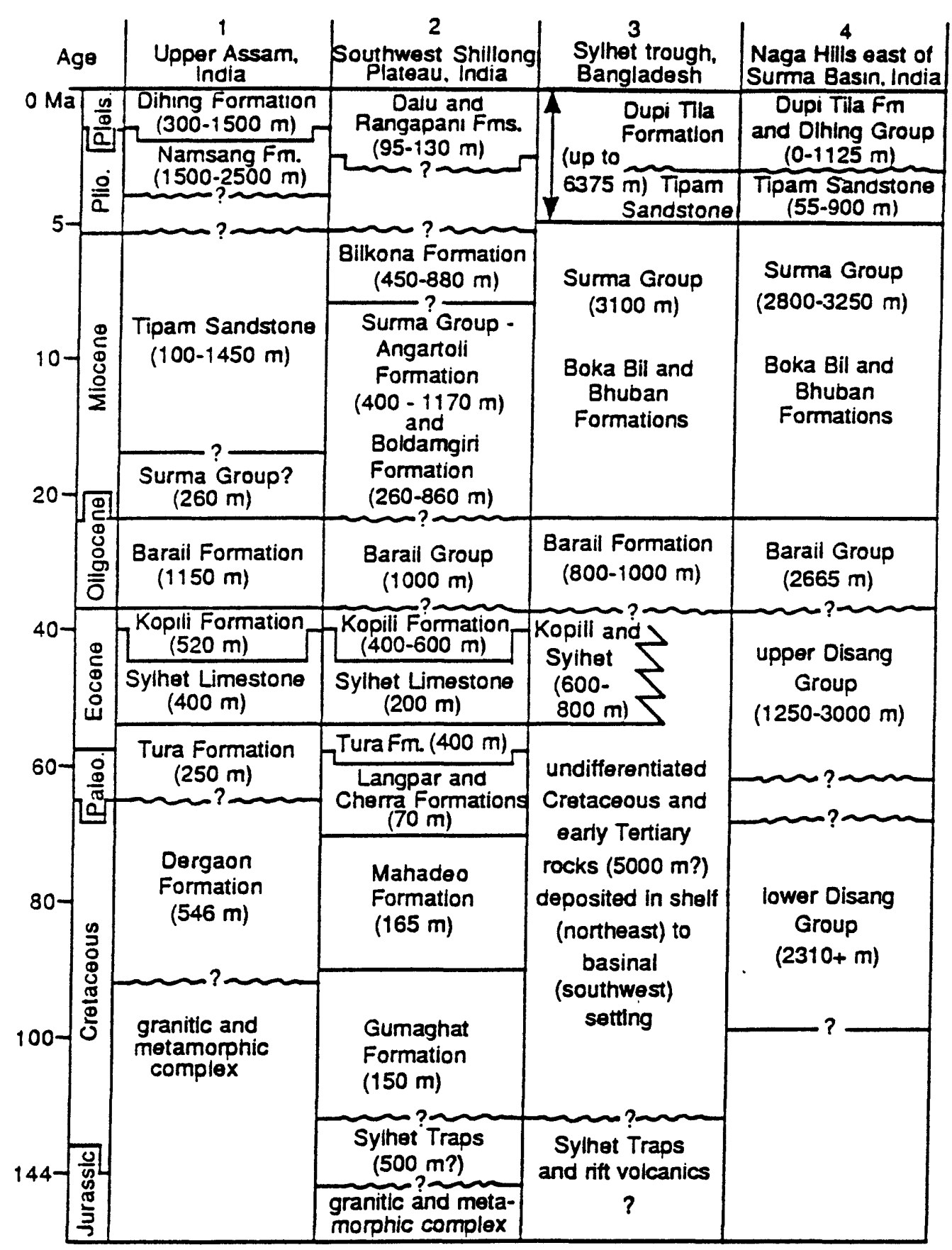

Figure 4. Chart showing the stratigraphy of the Sylhet trough and surrounding areas. The approximate locations of the numbered stratigraphic columns are shown in figure 1 . The latest Cretaceous Langpar Formation, Cherra Formation, Tura Formation, Sylhet Limestone, and Kopili Formation, comprise the Jaintia Group. Ages of nonmarine units (see text) are largely based on palynology and are approximate. Data from Baksi (1965), Holtrop and Keizer (1970), Chakraborty (1972), Gupta (1976), Murthy and others (1976), Banerji $(1981,1984)$, and Murty (1983). Note that the time scale is not linear. Wavy lines show unconformities. Time scale from Palmer (1983). 
the Dauki fault is most consistent with Pliocene and younger depositional patterns in the Sylhet trough, as discussed below. To the east, the Dauki fault may bend (with a change in dip) into the Haflong-Disang thrust fault as originally proposed by Evans (1964). To the west, offset on the Dauki fault may diminish and(or) the Dauki fault may be truncated by a north-trending structure, also discussed later in this paper.

\section{SYLHET TROUGH STRATIGRAPHY, SEDIMENTOLOGY, AND PETROLOGY}

The focus of this paper is the post-Eocene evolution of the Sylhet trough. The preOligocene history of the trough is briefly discussed below to provide a framework for subsequent discussions.

\section{Stratigraphy}

\section{Pre-Oligocene}

Pre-Oligocene rocks crop out on the northern (north of and within the Dauki fault zone) and eastern margins of the Sylhet trough ; they have not been penetrated by boreholes in the subsurface. Regionally, these rocks reflect mainly transgressive sedimentation on a passive margin (Banerji, 1981; Salt and others, 1986). Chakraborty (1972), Murthy and others (1976), and Banerji (1981) have described the Jurassic to Eocene deposits of the southern Shillong Plateau (fig. 4, column 2), comprising the following units in ascending order: 1) basaltic flows of the Jurassic(?) and(or) Cretaceous Sylhet Traps; 2) conglomeratic fluvial-estuarine deposits of the Lower Cretaceous Gumaghat Formation; 3) marginal-marine arkosic and glauconitic sandstone of the Upper Cretaceous Mahadeo Formation; 4) marginal-marine strata of the Upper Cretaceous to Paleocene Langpar and(or) Cherra Formations; 5) marginal-marine sandstone and mudstone of the Lower Eocene Tura Formation; 6) platform carbonate rocks of the Lower(?) to Middle Eocene Sylhet Limestone; and 7) prodeltaic to marginal-marine mudstones of the Upper Eocene Kopili Formation. This pre-Oligocene sedimentary section (above the Sylhet Traps) is approximately $1500 \mathrm{~m}$ thick.

East of the Sylhet trough in the Naga Hills of India (figs. 1 and 4, column 4), preOligocene rocks comprise the Disang Group, divided by Rangorao (1983) into lower and upper units. The Upper Cretaceous lower Disang unit (more than $2310 \mathrm{~m}$ thick) comprises slate, phyllite, and graywacke. It is unconformably overlain by the upper Disang unit (1250 to $3000 \mathrm{~m}$ thick), comprising mainly gray to black shale and minor sandstone. The correlative upper Disang shale and Sylhet Limestone crop out within $7 \mathrm{~km}$ of one another on the northeastern margin of the Sylhet trough in the Naga Hills (on opposite sides of the Dauki fault and Haflong-Disang thrust). Evans (1964) considered the Disang a geosynclinal facies and used this juxtaposition to support his model for large-scale lateral offset on the Dauki fault. However, Rangorao (1983) interpreted the upper Disang unit as a shallow marine deposit and suggested that the noted juxtaposition did not require large offsets.

The thickness relations described above, however, do suggest a shelf-to-basin transition between the correlative rocks in the southern Shillong Plateau (1600 m thick) and the Naga Hills (more than $3650 \mathrm{~m}$ thick). The Sylhet Limestone is a prominent seismic marker in the subsurface in the northwesternmost part of the Sylhet trough (Hiller and Elahi, 1984), suggesting that the shelf-to-basin transition, described in western Bangladesh by Salt and others (1986) on the basis of seismic data, lies in the vicinity of the Sylhet trough. The depositional facies relations described by Rangorao (1983) suggest a prograding shelf-slope setting that by Late Eocene time had filled in the proximal portions of the adjacent basin.

West of the Chhatak anticline in the northwestern part of the Sylhet trough (fig. 2), on BOGMC (Bangladesh Oil, Gas, and Minerals Corporation) seismic line PK-SU-6, the Sylhet Limestone reflector is underlain by roughly $2500 \mathrm{~m}$ (between 4.2 and 5.1 seconds, 
two-way travel time $=$ TWT) of stratified rock. (Inferred thicknesses of stratigraphic units from seismic data are based largely on the time-depth plot of Lietz and Kabir, 1982). If one assumes that the overlying Kopili Formation is the same thickness in the Sylhet trough as on the Shillong Plateau (about $400-600 \mathrm{~m}$ ), the pre-Oligocene section in the Sylhet trough is a minimum of about $2900 \mathrm{~m}$ thick. Previously Khan and others (1988) suggested on the basis of seismic data that pre-Kopili rocks in the Sylhet trough are $5000 \mathrm{~m}$ thick.

\section{Sedimentology}

A single, poorly exposed section of the Kopili Formation was examined along the south bank of the Dauki River west of Tama Bil and north of the Dauki fault (fig. 2). In the Dauki River outcrops, the Kopili consists of 1) thick, internally massive to poorly stratified beds of gray or black, calcareous, silty mudstone; 2) thin beds of laterally continuous, parallel- and ripple-laminated, calcareous, silty sandstone; and 3) thin to thick lenses and channel-form beds of calcareous, coarse-grained to very coarse grained sandstone containing abundant, fragmented fossil debris. Channel-form beds are as thick as $40 \mathrm{~cm}$ and commonly have $\geq 10 \mathrm{~cm}$ of erosional relief at their base. Ripple marks in silty sandstone are symmetrical, indicating formation by oscillating currents; horizontal grazing traces are commonly superimposed on ripple surfaces.

Coarse-grained beds containing abundant fossil debris represent lag deposits of winnowed and reworked coarse-grained sediment. There is no evidence of vigorous wave activity associated with deposition of the Kopili, so these lag deposits probably formed in tidal channels. The mudstone and silty sandstone are probably low-energy shelf deposits. The lack of primary stratification in the mudstone facies reflects extensive bioturbation.

\section{Sandstone Petrology}

One moderately well-sorted, fine-grained Kopili Formation sandstone was examined petrographically (appendix, table 2). Grains are subrounded and contain a high proportion of quartz, including a significant amount of polycrystalline varieties. The high quartz content, minor amount of feldspar, and small proportion of sedimentary lithic fragments suggest a source in a low-relief craton interior (Dickinson, 1985), partly underlain by sedimentary rocks. The small proportion of matrix ( 3.7 percent) formed by alteration of sedimentary lithic fragments.

\section{Stratigraphy}

\section{Oligocene}

Oligocene rocks comprising the Barail Formation crop out on the northern and eastern margins of the Sylhet trough, and have been penetrated in the subsurface only in the Rasidpur 2 and the Atgram IX wells. In the southwestern Shillong Plateau (figs. 1, 4), the Barail Group (the Barail has group status in parts of India) consists of about $1000 \mathrm{~m}$ of sandstone and carbonaceous shale of inferred deltaic and shallow-marine origin (Baksi, 1965; Chakraborty, 1972; Banerji, 1981). East of the Sylhet trough in the Naga Hills of India (fig. 1), the Barail Group is much thicker $(2665 \mathrm{~m})$ and comprises the following units in ascending order (Rangorao, 1983): 1) the Laisong Formation, comprising $885 \mathrm{~m}$ of thinto thick-bedded sandstone and minor carbonaceous shale of inferred delta-plain origin; 2) the 980-m-thick Jenam Formation, consisting mainly of shale, siltstone, and mudstone of prodelta, shallow-marine origin; and 3) the 800-m-thick Renji Formation, consisting of sandstone and subordinate carbonaceous shale of deltaic origin.

In the northwestern part of the Sylhet trough on the west end of BOGMC seismic line PK-SU-6 (west of the Chhatak anticline; fig. 2), the top of the Surma Group and the top of the Sylhet Limestone form prominent markers at about $3200 \mathrm{~m}(2.2$ seconds, TWT) and $7700 \mathrm{~m}$ (4.25 seconds, TWT), respectively. As discussed in the next section, the Surma Group is about $3100 \mathrm{~m}$ thick, so the cumulative thickness for both the Kopili Formation and the Barail Formation is about $1400 \mathrm{~m}$. Accordingly, we infer that the Barail Formation in the western Sylhet trough is about $800-1000 \mathrm{~m}$ thick, similar to the thickness on the 
Shillong Plateau. Khan (1978) reported just $645 \mathrm{~m}$ of Barail Formation (then mapped as the Jenam Formation of the Barail Group) in the Jaintiapur area on the northern margin of the Sylhet trough (fig. 2). The contact with the underlying Kopili Formation at this locality is not exposed, however, and it appears to be a fault or an unconformity on the basis of discordant bedding-plane attitudes. Other authors (for example, Holtrop and Keizer, 1970) have suggested much greater thicknesses $(2450-3350 \mathrm{~m}$ ) for the Barail Group in the Sylhet trough, but we could not reconcile their inferences with our interpretation of the available seismic data. In the present geographic framework, the Barail Formation clearly thickens basinward to the east and southeast, maintaining the pre-Oligocene pattern of a prograding shelf that filled the adjacent basin.

\section{Sedimentology}

The Barail Formation was examined in small, poorly exposed outcrops north of or within the Dauki fault zone, a few km east of Jaintiapur, in the town of Tama Bil, along the Dauki River-Tama Bil road, and on the south bank of the Dauki River (fig. 2). In these outcrops, the Barail Formation consists of multicolored (yellowish-brown, light-red, lightbrown, gray) sandstone; mottled reddish-orange and gray siltstone and mudstone; and yellowish-brown to reddish-brown intraformational conglomerate. Two distinct facies were observed. The Tama Bil-Dauki River outcrops represent the lower part of the Barail Formation and consist of alternating intervals (each as thick as several meters) of 1) fluvialchannel deposits, consisting mainly of fining-upward sequences of trough-crossbedded, parallel-bedded, and ripple-laminated, fine- to medium-grained sandstone, and 2) floodplain deposits consisting mainly of mottled silty mudstone and thin $(5-15 \mathrm{~cm})$, lenticular, amalgamated beds of fine-grained sandstone that form bedsets as thick as $150 \mathrm{~cm}$. The mottled mudstones are interpreted as paleosols with the loss of primary stratification attributed to pedogenic processes, including phytoturbation. The flood-plain sandstones are crevasse-splay deposits, with each bed representing deposition by a single flood and each bedset reflecting deposition in a single crevasse-splay lobe. The best examples of the crevasse-splay facies are exposed near Bathar Tila on the south side of the Dauki RiverTama Bil road. Collectively, the alternating channel and flood-plain deposits of the lower Barail form cycles of mixed-load, probably meandering river origin. Two nearly complete cycles are exposed in the Dauki River outcrops.

The outcrops east of Jaintiapur represent the upper part of the Barail Formation and consist of alternating beds (tens of centimeters to meters thick) of massive to crossbedded sandstone and intraformational conglomerate, bounded by erosion surfaces.

Intraformational sandstone and mudstone clasts are commonly cemented by hematite or contain ferruginous rims. Maximum dimension of clasts is as much as $5-6 \mathrm{~cm}$. The coarser texture of these strata and the abundant erosional bounding surfaces reflect deposition in rivers of greater competence than those that deposited the lower Barail. The iron-cemented and iron-rimmed intraformational clasts indicate that extensive pedogenesis and early diagenesis occurred on exposed portions of the alluvial plain flanking river channels. Flood-plain deposits were not observed in outcrops of the upper Barail Formation, probably due to their low preservation potential and(or) low resistance to weathering.

\section{Sandstone Petrology}

Eight samples of moderately well-sorted, fine- to medium-grained sandstones of the Barail Formation were examined petrographically (table 1; appendix, table 2; figs. 5B, 6B, 7). The sandstones have a high quartz content and are relatively low in feldspar. The ratio of plagioclase to total feldspar is highly variable $(0.61+/-0.19)$. Four samples have substantial hematite cements and(or) matrix, which formed by the alteration of unstable mafic minerals and(or) lithic fragments. This process resulted in an increased proportion of modal quartz relative to the primary detrital sediment. The samples contain a diverse suite of lithic grains, including sedimentary rock fragments (as much as 10.0 modal percent), 


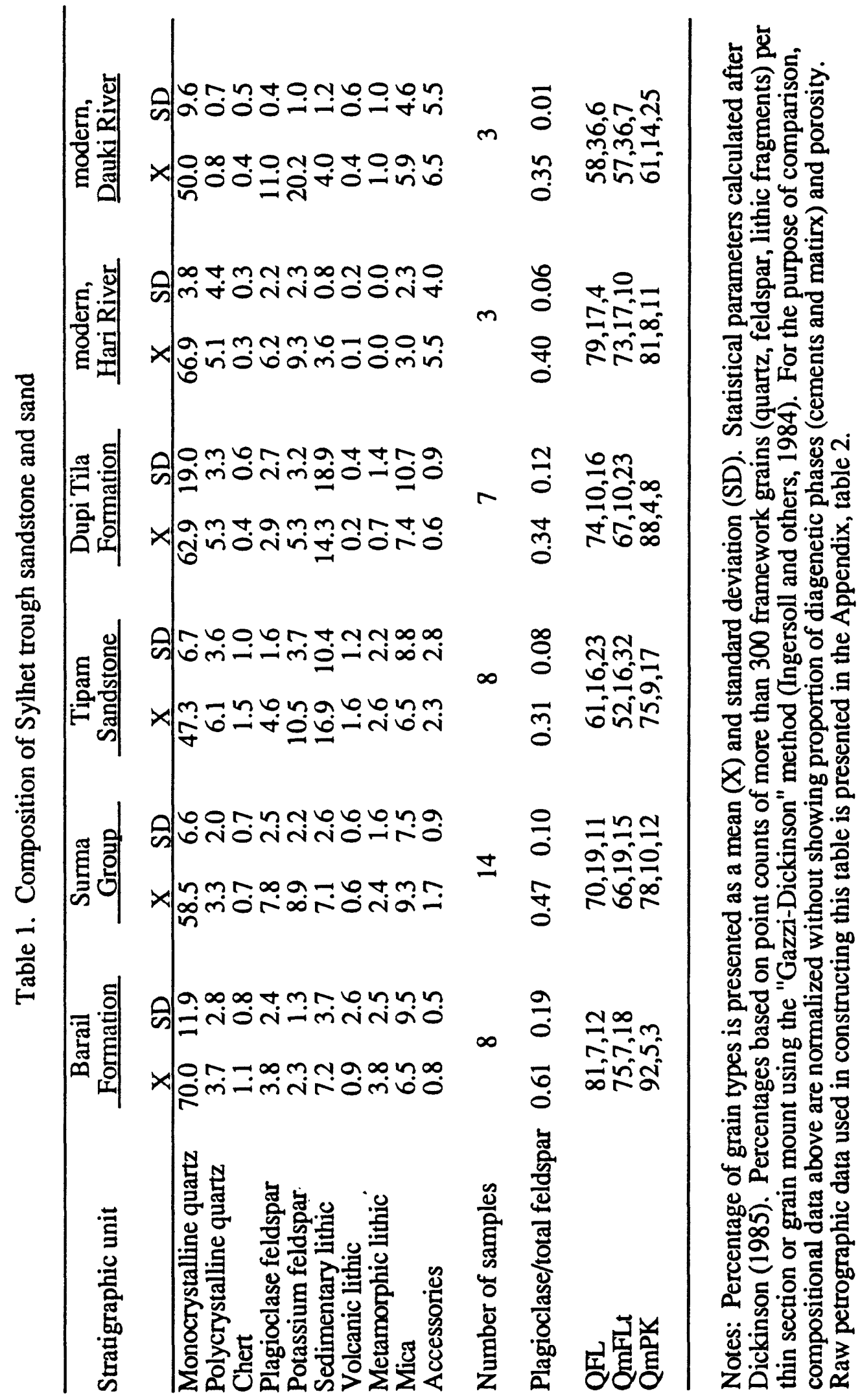



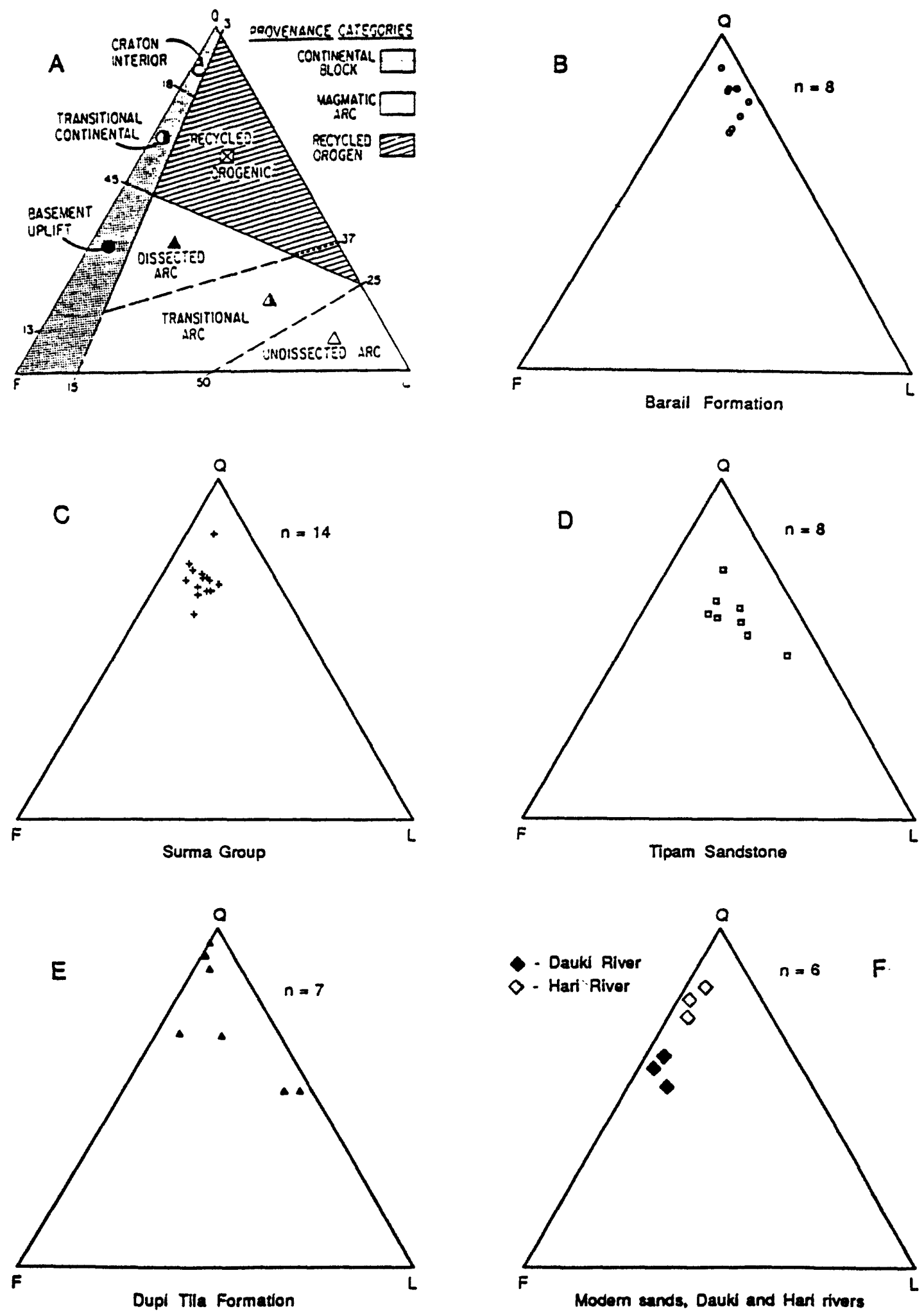

Figure 5. QFL (total quartz, feldspar, lithic fragments) ternary diagrams showing (A) the sandstone provenance fields of Dickinson (1985) and (B-F) composition of the sandstones and modern sands from the Sylhet trough. Compositional data are summarized in table 1. Raw petrographic data are in the appendix, table 2. 

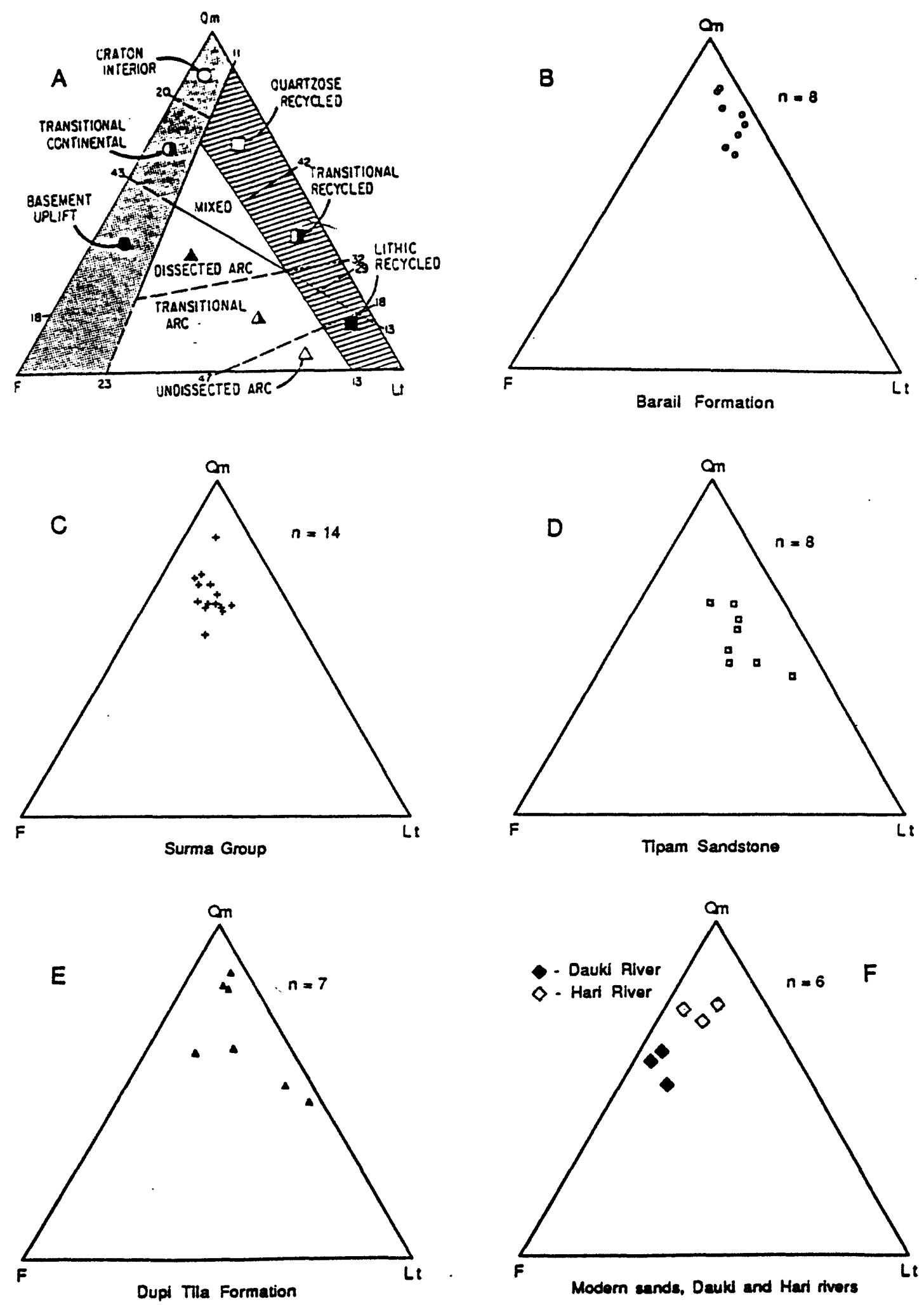

Figure 6. QmFLt (monocrstyalline quartz, feldspar, total lithic fragments) ternary diagrams showing (A) the sandstone provenance fields of Dickinson (1985) and (B-F) composition of the sandstones and modern sands from the Sylhet trough. Provenance field patterns are the same as in Figure 5. Compositional data are summarized in Table 1. Raw petrographic data are in the Appendix, Table 2. 


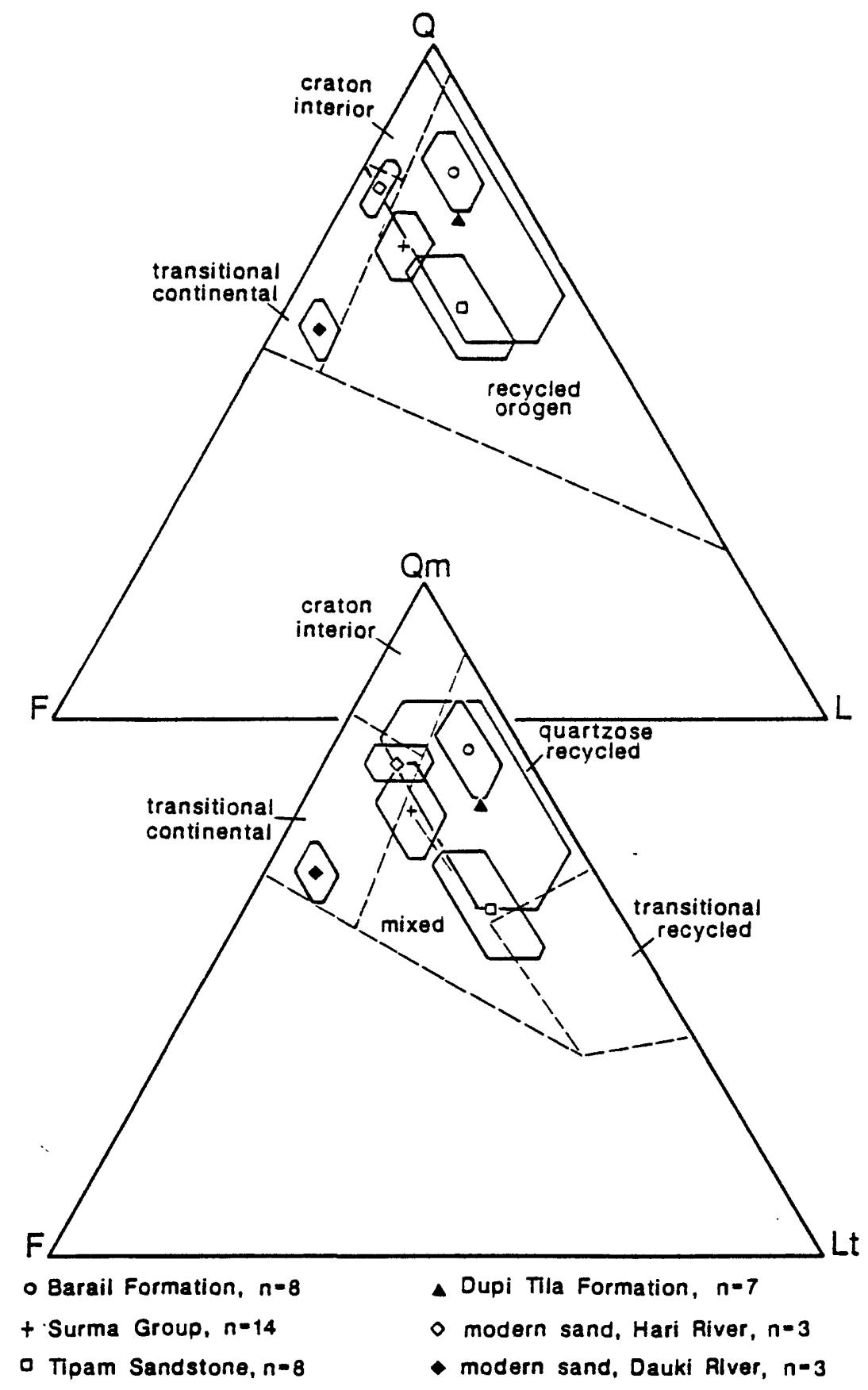

Figure 7. QFL (total quartz, feldspar, lithic fragments) and QmFLt (monocrystalline quartz, feldspar, total lithic fragments) ternary diagrams showing the mean (symbols) and standard deviation (solid hexagonal outlines) of compositions of Sylhet trough sandstones and modern sands, and the relevant sandstone provenance fields (enclosed by dashed lines) of Dickinson (1985). Individual points are plotted in figures 5 and 6. 
volcanic rock fragments (as much as 6.1 percent), quartz-mica tectonite fragments (as much as 5.4 percent), and low-grade metamorphic lithic fragments (as much as 3.2 percent). Many of the monocrystalline grains have quartz overgrowths interstitial to the early diagenetic hematite cement (and are thus remnant, having formed in the source terrane), further indicating a major source in sedimentary rocks. The samples fall in the "recycled orogen" provenance field on QFL (total quartz, feldspar, lithic fragments) diagrams, and in the "quartzose recycled orogen" provenance field on QmFLt (monocrystalline quartz, feldspar, lithic fragments) diagrams (figs. 5A, 6A, 7; Dickinson, 1985).

\section{Stratigraphy}

\section{Miocene to Early Pliocene}

The Surma Group has been divided into the Bhuban and Boka Bil Formations in Sylhet trough (for example, Khan and others, 1988). We detected no significant lithologic or petrologic differences between them, and therefore discuss them here as a single unit.

A complete thickness of the Surma Group was penetrated in the Atgram IX (2700 $\mathrm{m}$ ) and Rasidpur 2 (3109 m) wells (fig. 2). Approximately $3870 \mathrm{~m}$ of Surma Group was drilled in the Fenchuganj 2 well without reaching its base. The Surma Group (fig. 4) has a reported thickness of 2800-3250 $\mathrm{m}$ in the Naga Hills to the east (Rangorao, 1983), 660 to $2030 \mathrm{~m}$ in the southwest Shillong Plateau (Chakraborty, 1972; Banerji, 1984), and $260 \mathrm{~m}$ in northern Assam, India (Rangorao, 1983). The contact with the underlying Barail Formation is an apparent transgressive onlap, placed approximately at the OligoceneMiocene boundary (Banerji, 1984; Salt and others, 1986). The contact with the overlying Tipam Sandstone (where present) is clearly diachronous from Middle Miocene in Assam to Early Pliocene in Tripura, India (Shrivastava and others, 1974; Rangorao, 1983; Acharya and others, 1986). Holtrop and Keizer (1970) inferred that the Surma Group in the Sylhet trough is all Miocene, but Lietz and Kabir (1982), Banerji (1984), and unpublished BOGMC palynological reports suggest that its upper part is Early Pliocene.

\section{Sedimentology}

Cores and borehole geophysical logs of the Surma Group were examined from the Beani Bazar, Fenchuganj 2, Atgram IX, Habiganj 1, and Rasidpur 1 wells, and logs from six additional Sylhet trough wells (fig. 2). We also examined outcrops from the Madhabkund waterfall and along Lonely Chara on the west flank of the Patharia anticline, and east of Jaintiapur in low hills and along the banks of the Hari River (fig. 2). Four lithofacies were recognized and are discussed below in decreasing order of abundance.

Facies $\mathrm{A}$ is by far the most abundant, consisting of parallel-laminated gray to black mudstone and gray to yellowish-gray siltstone to very fine grained sandstone. The sandstone:mudstone ratio ranges from 1:5 to 1:20. The coarser siltstone and sandstone laminae are generally 1-5 mm thick (for example, see fig. 8), have planar to slightly undulatory upper and lower boundaries, and are laterally continuous (for as much as $20 \mathrm{~m}$ in the Hari River outcrops) to lenticular. Thicker laminae (>2 mm) are uncommonly ripple laminated. Several intervals as thick as $30-40 \mathrm{~cm}$ are characterized by soft-sediment folding and convolute lamination. The thickness of these deformed intervals suggests they formed by slumping. Small ( $2 \mathrm{~mm}>$ diameter) load casts and detached ball-and-pillow structures are also common. Small $(1 \mathrm{~mm}>$ diameter, $5 \mathrm{~mm}>$ depth) vertical burrows are rare.

Strata of Facies A are gradational with less common Facies B strata, which consist of thinly interbedded and interlaminated, very fine to fine-grained sandstone and silty mudstone. The sandstone: mudstone ratio ranges from about 5:1 to 1:5. Sandstone beds are as thick as $5 \mathrm{~cm}$ and are ripple to parallel laminated. Ripple sets are as thick as 2 to 3 $\mathrm{cm}$. The ripple sets are characterized by concave, undulating lower contacts. Foreset laminae within single ripple forms and within thin (less than $10 \mathrm{~cm}$ ) stratigraphic horizons commonly dip in opposing directions. Ripple cross-laminae are commonly strongly tangential to the lower set boundary and in some cases ascend the adjacent ripple form. 


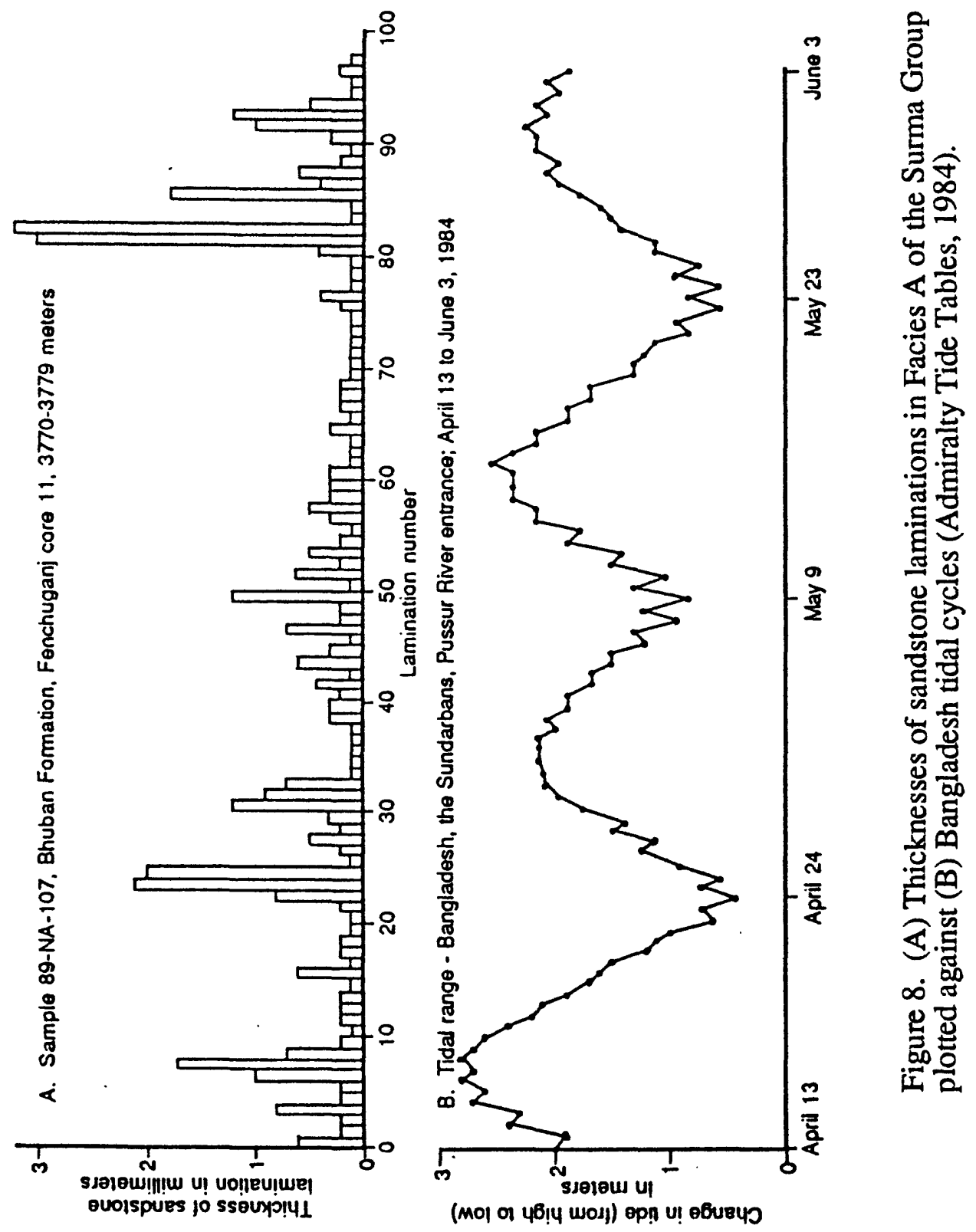


Ripple crests are symmetric, asymmetric, or planed off, and are commonly draped by mudstone laminae. The ripple marks are commonly form discordant, that is, the morphology of the ripple crest does not reflect the internal structure and geometry of the ripple. These ripples closely resemble those described in the "lenticular bed" facies of De Raaf and others (1977) and are of inferred wave-generated origin. Soft-sediment deformation structures, mainly load casts and ball-and-pillow structures $(10 \mathrm{~cm}>$ diameter), characterize intervals as thick as $10 \mathrm{~cm}$ in Facies B. Small vertical burrows (5 $\mathrm{mm}>$ diameter, $3 \mathrm{~cm}>$ depth) are rare.

Strata of facies A are also transitional to and interbedded with facies $\mathrm{C}$ strata, which consist of massive, silty to sandy mudstone. Dispersed sand grains and isolated small $(<5$ $\mathrm{mm}$ ) clots and curved lenses of sand are common. Although well-defined burrows are uncommon, the lack of stratification and the mixing of sediments of different grain size clearly reflects extensive bioturbation.

Facies D consists of massive, low-angle to hummocky(?)-bedded, and ripplelaminated, fine- to medium-grained sandstone. Only massive beds several meters thick were observed in cores. Uncommon abrupt textural inversions in these massive beds (for example, medium-grained sandstone overlying fine- to medium-grained sandstone) suggest that the thicker beds are amalgamated and represent several depositional events. The presence of mudstone rip-up clasts dispersed throughout the massive beds supports this interpretation. Vertical burrows a few $\mathrm{cm}$ in diameter are uncommon.

The only field example of the more coarse-grained Facies $\mathrm{D}$ was viewed at the Madhabkund waterfall. At this locality, about 30-40 m of the Surma Group are exposed in a cliff face, of which only the lower approximately $6 \mathrm{~m}$ are accessible. The lower 2-3 $\mathrm{m}$ of the exposure consist of gray, parallel- or ripple-laminated to massive, silty mudstone and sandstone (Facies A, B, C). The upper 3-4 m of the exposure consists of Facies D lowangle to hummocky(?)-bedded and ripple-laminated, fine-grained sandstone. Ripple sets are asymmetric, trough-shaped, and anomalously thick $(3-10 \mathrm{~cm})$, and climbing ripples are common. The contact between the upper (coarse-grained) and lower (fine-grained) parts of the exposure is abrupt and characterized by broad (several meters), deep ( $50 \mathrm{~cm}$ or more), elongate load casts.

Based on well-log interpretation, the Surma Group is characterized by sequences that range in thickness from about 40 to $275 \mathrm{~m}$. Sedimentologic analysis suggests the lower parts of these sequences consist of Facies A, B, and C strata, and show no systematic grain-size trends. The upper several meters of each sequence coarsen upward and are capped by Facies D sandstone. On seismic data (for example, fig. 3), the Surma Group is characterized by continuous to discontinuous banded reflectors.

Surma Group strata are interpreted as the prodelta and delta-front deposits of a large river-, wave- and tide-influenced, mud-rich delta system, probably similar to the modern Bengal delta (fig. 1). Facies D sandstones are inferred distributary-channel and proximal distributary mouth-bar deposits. Thick, massive, amalgamated sandstone beds with mudstone rip-up clasts suggest deposition in channels. Anomalously thick sets of ripple and climbing-ripple lamina suggest rapid deposition, probably where the channels broadened and rapidly deposited their sediment load on bars. Low-angle and(or) hummocky bedding suggest reworking of mouth-bar sediments by storm waves.

Facies B interbedded sandstones and mudstones were probably deposited on deeper parts of a channel-mouth bar, but above wave base. Sands and muds were probably transported to the mouth bar by flood and tidal currents, then the sands were reworked by oscillating currents into wave ripples. Mud drapes were deposited from suspension during periods of relative quiesence. The mouth bar or shelf of the present Bengal delta extends about $70 \mathrm{~km}$ offshore to a depth of about $20 \mathrm{~m}$, and sand is deposited as the mean grain size in some areas out to the shelf-slope break (Kuehl and others, 1989), The base of the steep part of the slope is about $90 \mathrm{~m}$ in depth, about $90 \mathrm{~km}$ from shore.

Mud-dominated Facies A strata were probably deposited in deeper parts of the mouth-bar or prodelta shelf; the common soft-sediment deformation of inferred slumping 
origin also suggests prodelta slope deposition. Facies A deposits resemble the "streaked mud" facies of De Raaf and others (1977). They interpreted the coarser sand or silt layers as suspension deposits of storms, slightly reworked by waves. Mudstone laminae are interpreted as intrastorm suspension deposits.

Alternatively, Facies A sediments may have been entrained by ebb-tidal currents and transported to the shelf as density underflows (hyperpycnal plumes). In this interpretation, sand laminae were deposited by these currents, and muddy laminae were deposited from suspension during slack and flood tide. Deposition of the Facies A sand laminae by tidal currents provides a mechanism for more rapid sediment accumulation compared to storm-induced deposition, which is consistent with the relative lack of bioturbation in Facies A strata.

Figure 8A shows the thickness of successive sandstone laminations in a 19-cmlong core of facies A from the Fenchuganj well (fig. 2). If these strata were deposited by tide-driven underlfows, then the thickness of each sandstone lamination should provide a measure of the strength of the ebb-tidal current and thus be directly related to the magnitude of tidal range. Plotted against this chart is a graph of tidal ranges for a 50-day period for the Pussur River entrance of the Sundarbans, Bangladesh, showing about three and onehalf tidal cycles (fig. 8B). Each plot shows 4 peaks having similar wavelengths; the tidalrange graph is more regular. The second and third peaks on the lamination-thickness chart are displaced to the left of their possible tidal equivalent, suggesting that, if tidal currents were important, not every ebb tide produced a recognizable sandstone laminae. The fourth sandstone-thickness peak is slightly displaced to the right of its predicted location, a possible result of identifying closely spaced, thin laminae of a single depositional event as the deposits of two events. The coincidence of the peaks in figure 8 supports, but does not prove, transport by tidal currents.

Wright and others (1988) described tide-driven density currents off the Yellow River delta in China, and suggested that a continual fluvial supply of suspended sediment is a requirement for the noted hyperpycnal flows. A relatively high tidal range (as much as 6 $\mathrm{m})$, strong tidal currents $(3.8 \mathrm{~m} / \mathrm{sec}$ maximum), and enormous suspended-sediment loads characterize the modern Bengal delta (Coleman, 1969; Kuehl and others, 1989). Miocene deltas in Bangladesh, with a similar geographic configuration, were not doubt characterized by similar processes and sediment loads. Other possible ancient prodelta-tidal deposits have been described by Williams (1989).

Facies $\mathrm{C}$ represents finer grained equivalents of facies $\mathrm{A}$, similarly deposited in an inferred prodelta shelf-bar setting. The bioturbation-induced destratification reflects decreased sediment accumulation rates probably associated with delta-lobe abandonment.

Summarizing, the Surma Group in the Sylhet trough is interpreted as the deposits of a river-, wave- and tide(?)- influenced delta, with sedimentation in prodelta shelf and slope, mouth-bar, and distributary-channel environments. Using the modern Bengal delta as an analogue, paleobathymetry probably ranged from a few meters (channel and bar) to less than $100 \mathrm{~m}$ (prodelta slope). Given this limited paleobathymetric range and the long time period inferred for Surma Group deposition (fig. 4), it is surprising that neither subaerial nor deeper-water deposits were recognized. Sediment accumulation and subsidence appear to have maintained a remarkably. long-lived equilibrium. The prodelta shelf and slope of this Miocene delta appears to have been broad ( $\geq 70 \mathrm{~km}$ wide), comparable to that of the modern Bengal delta (Coleman, 1969). Curtis (1970) suggested that, when rates of subsidence and deposition are equal, deltas will build vertically and spread laterally, a suggestion consistent with these observations.

The contact of the Surma Group and the overlying Tipam Sandstone is exposed at Lonely Chara (west flank of Patharia anticline) and along the Hari River (fig. 2). Along Lonely Chara, there is a significant, coarsening-upward facies change in the upper, approximately $10-15 \mathrm{~m}$ of the Surma Group. Facies remain mainly parallel- and ripplelaminated, but the sandstone:mudstone ratio rises significantly, sandstone laminations and beds become thicker and more continuous, ripple sets become thicker, and there are two 
lenticular interbeds (10-20 cm thick) of massive, poorly sorted conglomerate (probably intraformational) containing angular to rounded sedimentary clasts. All these facies changes suggest shoaling, consistent with the upward transition to the nonmarine Tipam Sandstone. The contact between the Tipam and the Surma Group is erosional and may be a local unconformity. This type of surface also characterizes the Tipam-Surma contact along the Hari River. However, the transitional, shoaling-upward facies seen in the Lonely Chara section were not present in the Hari River outcrops.

\section{Sandstone Petrology}

Fourteen thin sections of fine- to medium-grained sandstones from the Surma Group were examined (table 1; appendix, table 2; Figs. 5C, 6C, 7). Strata are generally arkosic arenites, and have very similar framework-grain compositions (mean QFL =70,19,11). Quartz is generally monocrystalline and includes some grains with remnant overgrowths. The plagioclase/total feldspar ratio is $0.47+/-0.10$. Lithic fragments are mainly sedimentary (as much as 10.4 percent in one sample), and quartz-mica tectonite fragments are also present in significant amounts (as much as 3.9 percent). Mica, mainly biotite, is very common and in some samples abundant (as much as 20.9 percent). The QFL modes plot in the "recycled orogen" provenance field, and the QmFLt modes plot in the "mixed," "transitional continental," and "quartzose recycled orogen" fields (Dickinson, 1985).

The abundance of mica, presence of sedimentary and quartz-mica tectonite fragments, and evidence for a sedimentary source of some quartz grains favors a partial sedimentary or metasedimentary source. There is minimal overlap between the Surma Group and Barail Formation sandstones on ternary diagrams (none on the standard deviation plots of fig. 7); they are distinguished on the basis of relatively more quartz and less feldspar in the Barail. Some feldspar grains are partly dissolved in many Surma Group samples, an effect that would diminish the noted Surma-Barail distinction from the original detrital sediment.

Feldspar and calcite cement dissolution are common in many samples; sandstones buried as deeply as $3000 \mathrm{~m}$ to $4425 \mathrm{~m}$ have as much as 15 percent porosity. This secondary porosity is probably related to migration of organic acids associated with the maturation of organic matter, as inferred by Imam and Shaw (1985).

\section{Stratigraphy}

\section{Pliocene to Pleistocene}

The Tipam Sandstone and the Dupi Tila Formation comprise the Pliocene and Pleistocene deposits of the Sylhet trough. Both units crop out only on the uplifted trough margins. The two units can be identified easily on seismic records (fig. 3 ). The Tipam Sandstone is a nearly massive, coarse-grained unit having limited internal variability. Hence it is seismically homogeneous and has few internal reflectors. This massive seismic character is easily contrasted with the banded reflectors of the underlying Surma Group and the overlying Dupi Tila Formation. The Dupi Tila and, to a much lesser degree, the Tipam each thin over anticlinal crests (fig. 3; Hiller and Elahi, 1984), indicating that they were deposited synchronously with folding. Based on seismic interpretation (for example, fig. 3), the Tipam-Dupi Tila contact appears conformable in synclines but is commonly an angular unconformity near anticlines. Mapping studies (for example, Khan, 1978) document the local angular unconformities.

The maximum penetration of the.Tipam-Dupi Tila section in a well is about $2440 \mathrm{~m}$ (Beani Bazar, fig. 2); however, Sylhet trough wells have been drilled on anticlinal crests where the minimum section is encountered. In a mapping study in the Jaintiapur area on the northern margin of the Sylhet trough, Khan (1978) reported a thickness of $2271 \mathrm{~m}$ for the Tipam Sandstone and $2393 \mathrm{~m}$ for the Dupi Tila Formation. Seismic lines reveal even greater thicknesses in synclinal areas. In the Goyain and Kushiara synclinal troughs on the flanks of the Sylhet anticline (fig. 2), the Tipam-Dupi Tila section is about $6375 \mathrm{~m}$ thick $(3.65 \mathrm{sec}$. TWT) and $6000 \mathrm{~m}$ thick (3.3 sec. TWT), respectively (BOGMC seismic line 
PK-SU-3). These thickness estimates are consistent with the seismic interpretations of Lietz and Kabir (1982) and Hiller and Elahi (1984), who used the same data set.

The Tipam-Dupi Tila section thins to the south (figs. 2,9), where the maximum thickness in a synclinal trough (between Rasidpur and Habiganj anticlines) is about $3200 \mathrm{~m}$ line (2.2 sec, TWT, BOGMC seismic line T-3). Farther to the west in the undeformed part of the Sylhet trough (about $60 \mathrm{~km}$ west of the Chhatak anticline), the Tipam-Dupi Tila interval thins from about $3200 \mathrm{~m}$ (2.2 sec. TWT, line PK-SU-6) about $10 \mathrm{~km}$ south of the Dauki fault, to $1500 \mathrm{~m}$ thick $(1.15 \mathrm{sec}$. TWT, line R4) about $100 \mathrm{~km}$ to the south. Some of this thinning (a few hundred meters?) may reflect interfingering between the Tipam Sandstone and the underlying Surma Group (fig. 9).

As discussed below, the Tipam Sandstone is regarded as predominantly bed-loaddominated (probably braided) river deposits and the more fine-grained strata of the Dupi Tila Formation as mixed-load (probably meandering) river deposits. The contact between these two units (except near anticlinal crests) is probably gradational and transitional from north to south, reflecting distance from the inferred source terrane. Some workers have recognized an upper unit, the Girujan Clay, at the top of the Tipam, but we follow

Rangorao (1983) in suggesting that the Girujan is primarily a lateral, flood-basin equivalent of Tipam channel deposits having only local utility as a stratigraphic unit.

The Tipam-Dupi Tila section overlies the Surma Group in the Sylhet trough and is therefore Pliocene and younger. Farther north, in Assam (fig. 1), the contact between the Tipam and the underlying Surma Group is somewhat arbitrary, and the Tipam is Miocene in age (fig. 4; Rangorao, 1983). The Tipam Sandstone and its Pliocene correlatives are absent from the Shillong Plateau (Murthy and others, 1976).

\section{Sedimentology of the Tipam Sandstone}

The Pliocene Tipam Sandstone was examined in two localities, along the Hari River east of Jaintiapur and in the bed of Lonely Chara on the west flank of the Patharia anticline (fig. 2). In both areas, the lower contact with the Surma Group is exposed (see above), but the upper contact is either not exposed or was not observed. In these localities, the Tipam is well exposed along the Hari River where it consists predominantly of thick, vertically stacked beds of yellowish-brown to yellowish-orange, medium-grained to pebbly sandstone. Strata are characterized by large-scale scours (laterally continuous for tens of meters) and internal erosion surfaces (typically with tens of centimeters of erosional relief over several meters of lateral exposure), trough and planar crossbedding (sets as thick as $150 \mathrm{~cm}$ ), and flat- to low-angle bedding. Clasts include both crystalline and sedimentary lithologies (including mudstone rip-up clasts). Fine-grained interbeds were not observed in outcrops. Well logs and seismic data (which show few internal reflectors) similarly suggest little lithologic variability and a dominantly sandstone composition.

The coarse texture, large-scale sedimentary structures, and vertical sedimentary sequence suggest deposition in a bedload-dominated (probably braided) fluvial system. The presence of fine-grained intraformational clasts indicates that these rivers were at times flanked by flood plains on which fine-grained sediments were deposited and subsequently eroded.

Approximately $30 \mathrm{~m}$ of the lowermost part of the Tipam Sandstone is exposed in the bed of Lonely Chara. These strata appear to have texture and sedimentology similar to those of the Hari River section, but the quality of outcrop precludes detailed description or interpretation.

\section{Sedimentology of the Dupi Tila Formation}

Outcrops of the Pliocene and Pleistocene Dupi Tila Formation were observed along the Hari River east of Jaintiapur and in the Moshegull section on the west flank of the Patharia anticline (fig. 2). The lower contact with the Tipam Sandstone was not exposed in either of these anticlinal areas but is clearly an angular unconformity on the basis of discordant bedding-plane attitudes. The upper contact with modern sediments is exposed 


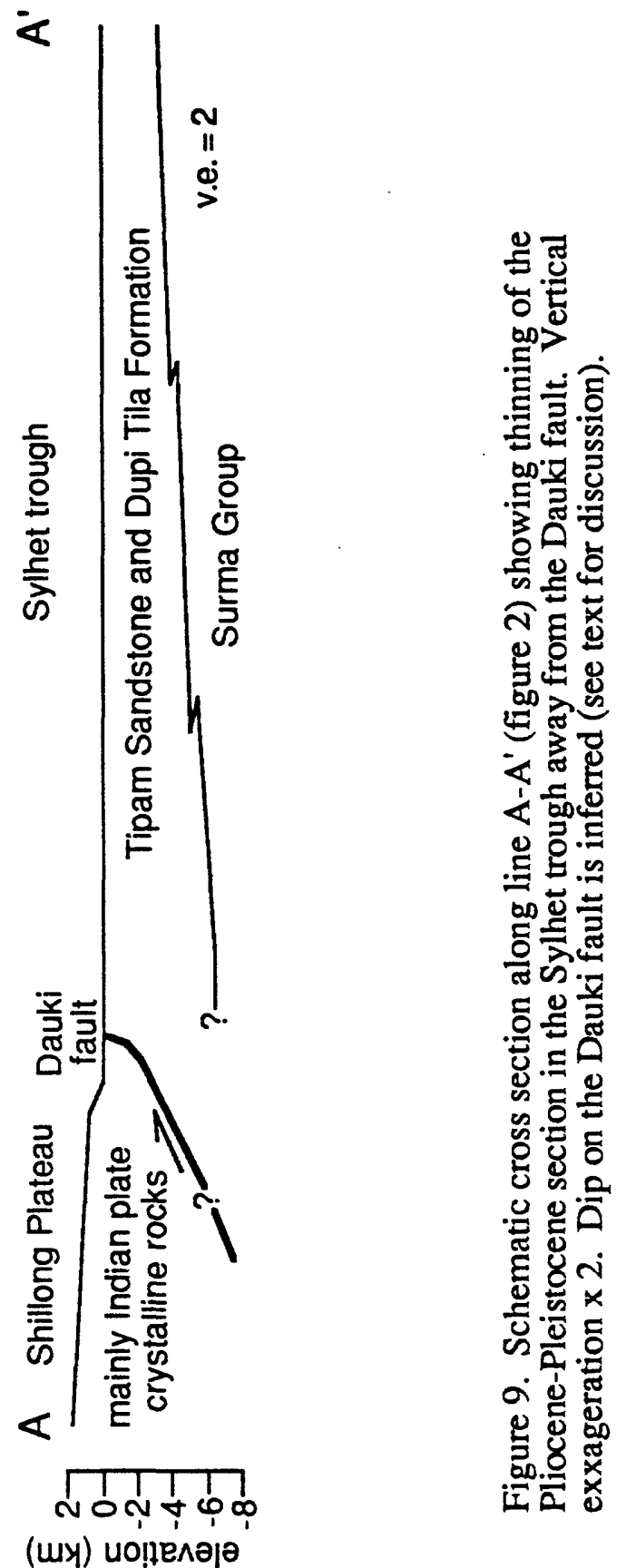


in both areas and is also an angular unconformity. In both areas of exposure, the Dupi Tila consists of altermating intervals of fluvial-channel and flood-plain deposits. Channel deposits are generally 2-4 m thick, have erosional bases (with tens of centimeters of erosional relief), consist of trough crossbedded and flat- to low-angle bedded, fine- to coarse-grained sandstone, and generally fine upward. Trough crossbed set thicknesses and widths generally range from 10 to $50 \mathrm{~cm}$ and 50 to $100 \mathrm{~cm}$, respectively. Sand grains in some of the channel units are relatively fresh, whereas in other units they are deeply weathered to clays. In the latter cases, primary sedimentary structures (crossbeds, erosional scours, and so forth) are well preserved in the secondary clays. Flood-plain deposits consist of mottled, yellowish-brown to gray, silty clay paleosols. Root casts and ferruginous nodules are common; primary sedimentary structures have been obliterated. Several well-developed paleosol profiles marked by zoned color contrasts stand out in the Hari River outcrops.

The alternating channel and flood-plain deposits of the Dupi Tila Formation in the two areas are organized into fining-upward cycles of probable meandering river origin. The best examples of complete, well-exposed cycles (thicknesses of 6-12 m) are exposed along the Hari River.

\section{Sandstone Petrology of the Tipam Sandstone}

Eight samples of fine- to medium-grained sandstone were examined petrographically (table 1; appendix, table 2; figs. 5D, 6D, 7). These sandstones are lithic arenites. Monocrystalline quartz grains have common remnant overgrowths, indicating derivation from a sedimentary source. Polycrystalline quartz is particularly abundant (6.1 $+/-3.6$ percent). Plagioclase/total feldspar ratio varies little among samples $(0.31+/-.06)$. Sedimentary rock fragments are the most common lithic fragment $(16.9+/-10.4$ percent $)$, but quartz-mica tectonite fragments are also common $(2.3+1-2.0$ percent). Sedimentary rock fragments include silty quartzite (some grains are internally cemented by hematite) and mudstone. Mica, especially biotite, is a common accessory mineral. Sandstone compositions plot in the "recycled orogen" provenance field on a QFL diagram, and near the boundary of the "quartzose recycled orogen," "transitional recycled orogen," and "mixed" provenance fields on a QmFLt diagram (Dickinson, 1985). Based on their larger proportion of lithic fragments, Tipam Sandstone samples are clearly distinct from samples of the Barail Formation and Surma Group (fig. 7).

\section{Sandstone Petrology of the Dupi Tila Formation}

Seven fine- to medium-grained sandstone samples of the Dupi Tila Formation were examined petrographically (table 1; Appendix, table 2; figs. 5E, 6E, 7). These samples showed a far greater range of composition than the older suites of samples analyzed, in large part due to the effects of weathering and early diagenesis. The least altered sample (S-89-B30) contains 41.5 percent sedimentary lithic fragments and 4.3 percent biotite. The most quartz-rich samples contain the most hematite cement and(or) matrix, which clearly formed through alteration of unstable mafic minerals and lithic fragments. Partly dissolved feldspar grains are also present in most of the samples. Thus, most of the compositions listed in table 2 and plotted on figures 5-7 are enriched in quartz relative to the original detrital sediment. Quartz grains generally show fewer remnant overgrowths than do samples from older rock units and may therefore have increased derivation from primary crystalline sources. Plagioclase/total feldspar is $0.34+/ 0.12$.

Because of the variable amount of alteration, sandstones plot in broad fields on ternary diagrams. The least altered samples, which most accurately reflect the primary detrital sediment, plot in the "recycled orogen" provenance fields of Dickinson (1985). These least altered samples are similar in composition to the Tipam Sandstone. 


\section{Petrology of river sands}

\section{Modern sediments}

For comparison, six samples of medium sand from the Dauki and Hari Rivers a few kilometers south of the Dauki fault (fig. 2) were collected and analyzed petrographically (table 1; Appendix, table 2; figs. 5F, 6F, 7). The compositions of these samples varies from river to river, reflecting local Shillong Plateau sources. Hari River sand is richer in quartz, plotting in the "transitional continental" to "craton interior" provenance fields on QFL diagrams and in the "transitional continental" field on the QmFLt diagram (Dickinson, 1985). Dauki River sands contain more feldspar, and plot in the "transitional continental" provenance field on both ternary diagrams. The Dauki River sand composition does not overlap with any of the ancient samples, and the Hari River sand overlaps only partly with the sandstone of the Surma Group in the QFL diagram. These samples are fresh and have not been affected by surface weathering or diagenesis. There is no secondary process that could lead to an increase in the proportion of lithic fragments, which would be needed for more overlap between these samples and Sylhet trough sandstone samples.

\section{BASIN EVOLUTION}

The Sylhet trough has undergone a complex evolution recording the transition from a passive, rifted continental margin, to a foreland basin on the margins of two mobile belts, the Indo-Burman ranges and the Himalayas. The geohistory and paleogeographic diagrams of figures 10 and 11 illustrate this evolution. Five points were used in constructing the geohistory plots, conforming to the above discussions. We assumed that sedimentation was essentially continuous and that unconformities are either local or of short duration (fig. 4), consistent with seismic interpretations. Deposition is assumed to have begun about 120 $\mathrm{Ma}$, shortly following rifting and opening of the Indian Ocean (Curray and others, 1983). A thickness of $5500 \mathrm{~m}$ was assigned to the section between the basement and the top of the Kopili Formation (Khan and others, 1988). Although we were not able to confirm this thickness with available seismic data, it is consistent with reported thicknesses from the Naga Hills to the east in India (fig. 4; Rangorao, 1983). Based on our seismic analysis, we assigned a 900 -m-thickness to the Oligocene Barail Formation. A thickness of $3100 \mathrm{~m}$ was assigned to the Surma Group, an intermediate value between maximum and minimum thicknesses penetrated in wells. The thicknesses for both the Barail Formation and the Surma Group may vary within the Sylhet trough; however, these variations can not be documented with the available well and seismic data. For the Tipam Sandstone and Dupi Tila Formation, we show thicknesses of $6375 \mathrm{~m}$, representing the deepest synclinal depocenters (fig. 10A), and $3200 \mathrm{~m}$, representing the section in the western, flat-lying part of the Sylhet trough (fig. 10B). Strata in the Sylhet trough therefore have a total thickness of about 12,700 to $15,875 \mathrm{~m}$.

The pre-Oligocene history (fig. 11A) represents the passive margin phase of basin evolution. Shelf facies to the north and northwest graded southeast into basinal facies, with the intervening slope probably occurring near the northwestern part of the Sylhet trough. The shelf facies appears to have prograded over the slope in the Sylhet trough by the Late Eocene (Rangorao, 1983). Due to lack of subsurface data, a constant subsidence rate was assumed on the geohistory diagrams between $120 \mathrm{Ma}$ and the Eocene-Oligocene boundary. It seems likely, however, that subsidence would resemble that of other passive margins, which display concave burial history curves that reflect initial rapid subsidence as an isostatic response to crustal thinning, followed by a slower, post-rifting phase of subsidence driven by thermal reequilibration of the mantle and lithosphere (for example, Watts and Steckler, 1979). 

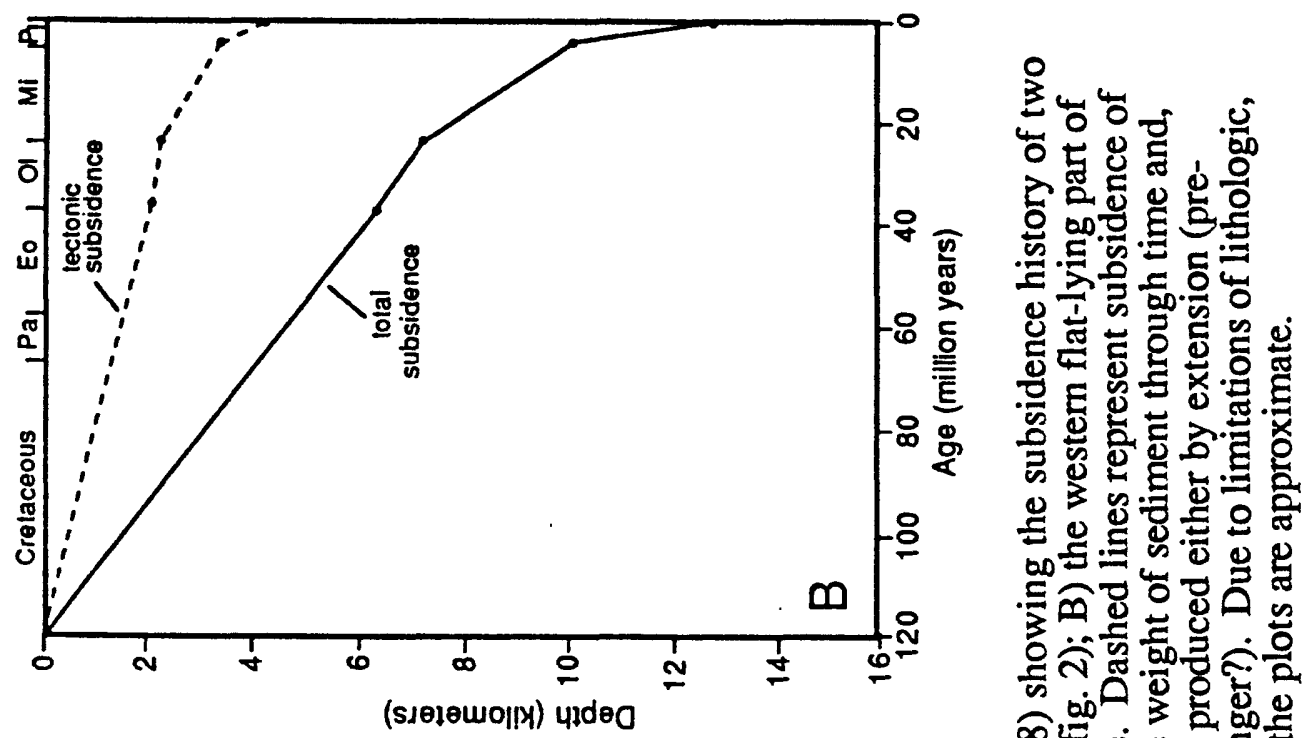

○造

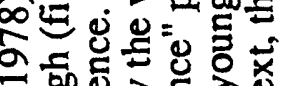

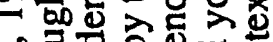

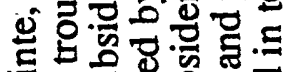

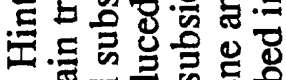

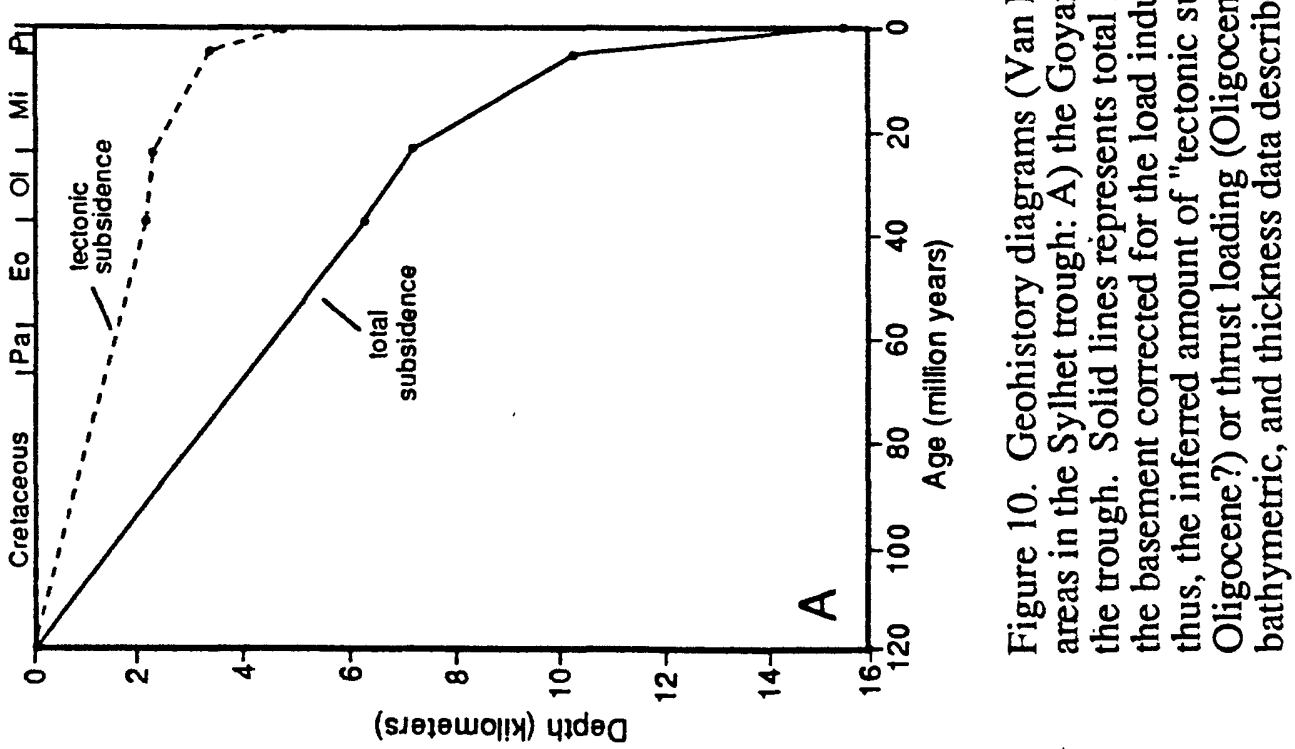



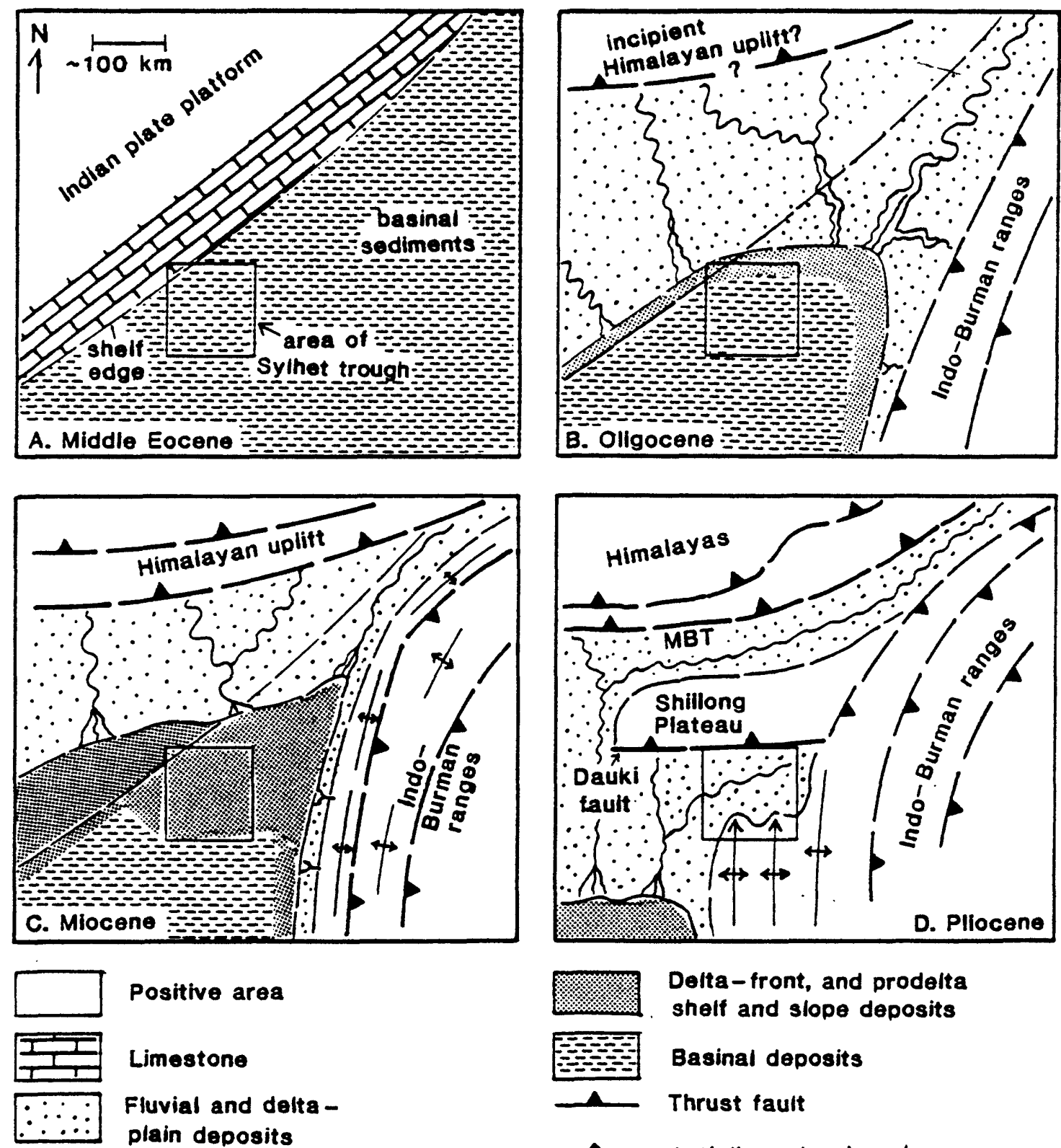

Positive area

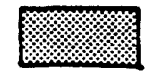

Delta - front, and prodelta shelf and slope deposits

Limestone

Fluvial and delta plain deposits

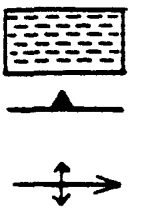

Basinal deposits

Thrust fault

Anticline, showing plunge

Figure 11. Schematic paleogeographic reconstructions showing four stages in the Cenozoic evolution of the Sylhet trough. Reconstructions in A, B, and C restore inferred Shillong Plateau southward displacement. MBT = Main Boundary thrust fault. See text for discussion. Other schematic paleogeographic reconstructions for this area are in Rangorao (1983) and Banerji (1984). 
Subsidence during the Oligocene is shown as continuing at about the same rates as in the pre-Oligocene but, given the general trends for passive margins described above, the slope of the curve may represent a small acceleration. Brunnschweiler (1966) and Rangorao (1983) suggest that orogenic uplift began in the Indo-Burman ranges at this time (fig. 11B), and it is likely that crustal loading from thrusting in this nearby orogeny affected the Sylhet trough and areas to the east. This relation provides an explanation for the greater thickness of the Barail Group east of the Sylhet trough in the Naga Hills (figs. $1,4)$, which would have occupied a position in the more rapidly subsiding, proximal part of a foreland basin. Rangorao (1983) interprets the Barail of the Naga Hills as mainly deltaic and shows a marine embayment (his fig. 27C) in this more proximal setting. It therefore seems unlikely that Barail Formation sandstones on the northern margin of the Sylhet trough were derived from the Indo-Burman ranges (they would need to have been transported across the inferred marine embayment to get there). Instead, Barail sediments were probably derived from northern and northwestern sources in incipient Himalayan uplifts, with rivers flowing toward the marine trough in the more rapidly subsiding part of the basin. Barail sandstone compositions (figs. 5B, 6B, 7) suggest recycled orogenic sources (but plot near the craton interior field), consistent with this inference. Oligocene clastic detritus buried the Eocene carbonate/clastic shelf and probably record the transition from passive-margin to convergent-margin sedimentation in the eastem Himalaya. In figure 11B, Oligocene deltas are shown slightly north of the Sylhet trough, a reconstruction that subtracts the inferred southward tectonic transport of the Shillong Plateau discussed in the following section.

Subsidence rates clearly accelerated during the Miocene (fig. 10) when the Surma Group was deposited during a prolonged transgression that extended northward to the Mikir Hills and over at least parts of the Shillong Plateau (figs. 1, 4, 11 C; Banerji, 1984; Salt and others, 1986). This greater rate of subsidence probably reflects increased proximity to and loading from the encroaching Indo-Burman ranges. Crustal loading from the Himalayas may have had a minor effect; however, the thrust front (Main Central thrust fault) of the uplifting Himalayas was located much farther from the Sylhet trough than the Indo-Burman ranges at this time, and the Miocene section in this region does not thicken to the north (fig. 4). Surma Group sandstone compositions record derivation from recycled orogenic, mixed, and transitional continental sources, and have more feldspar than Barail Formation sandstones (figs. 5-7). This increased feldspar content suggests derivation from crystalline rocks, uncommon in the Indo-Burman ranges but a significant component of the eastem Himalayas (Ray, 1982; Molnar, 1984). The Shillong Plateau, also underlain by crystalline rocks, was at least partly submerged at this time, so sediment derivation from the Himalayas seems highly likely. The transition in composition from the Barail Formation (for which a Himalayan provenance is also inferred) to the Surma Group records progressive Himalayan unroofing. Sedimentary facies data indicate the Surma Group delta system was large and laterally extensive, suggesting that the rapidly subsiding trough on the western flank of the Indo-Burman ranges (of which the Sylhet trough was a part) may have drained a large proportion of the eastern Himalayas.

The Pliocene and Pleistocene history of the Sylhet trough (fig. 11D) is characterized by much higher ( 3 to 8 times) subsidence rates (as much as $1250 \mathrm{~m} / \mathrm{million}$ years) than those recorded for Miocene deposition of the Surma Group (fig. 10). As described earlier, the Dupi Tila Formation and, to a lesser degree the Tipam Sandstone, thin over anticlinal crests (fig. 3; Hiller and Elahi, 1984), indicating that the frontal zone of Indo-Burman ranges deformation had advanced into the eastern Sylhet trough in middle to late Tipam Sandstone time (late Early to early Late Pliocene?). The Sylhet trough continued to subside rapidly after the folding associated with the advancing Indo-Burman ranges commenced. Therefore, it seems likely that only some (early and minor?) of this increased rate of subsidence can be attributed to increased crustal loading from this orogenic belt. The frontal thrust of the Himalayas (by this time the Main Boundary thrust fault) was more than $150 \mathrm{~km}$ away and could not have created this large effect. We propose that this dramatic 
subsidence was mainly forced by south-directed overthrusting of the Shillong Plateau along the Dauki fault. Two additional lines of evidence support this inference. First, the noted southward thinning of the Tipam-Dupi Tila interval (for example, figs. 2, 9) supports crustal loading on the northern basin margin; folds that have considerable topographic relief in the Tripura area of the Indo-Burman ranges on the southern basin margin plunge into the subsurface of Sylhet trough (figs. 1,2). Second, both gravity and seismotectonic data are most consistent with a north-dipping thrust below the Shillong Plateau (Seeber and Armbruster, 1981; Molnar, 1987).

Major uplift of the Shillong Plateau clearly began in the Pliocene. There is no record of significant Pliocene-Pleistocene deposition on the Shillong Plateau (fig. 4), consistent with its interpretation as an emerging block. The facies change between the mainly fine-grained, prodelta Surma Group to the coarse-grained, braided fluvial Tipam Sandstone indicates an abrupt change in basin geometry and tectonics. The Surma GroupTipam Sandstone transition is also marked by a change in sandstone petrology (figs. 5-7), which suggests a new sediment source. The significant increase in sedimentary lithic fragments in the Tipam probably reflects erosion of the sedimentary cover of the uplifting Shillong Plateau and to a lesser extent, erosion of the Indo-Burman ranges. The petrology of the Dupi Tila Formation similarly reflects a recycled orogen source. Only very recently, as recorded in modern fluvial sands (figs. 5-7) that plot in transitional continental and craton interior provenance fields, has the crystalline basement of the Shillong Plateau been exposed.

Uplift of the Shillong Plateau also led to a major reorganization of rivers draining the Himalayas. The Brahmaputra River, which probably flowed into the Surma Group delta during the Miocene (fig. 11C), was apparently deflected about $300 \mathrm{~km}$ to the west to its present course skirting the Shillong Plateau (fig. 1).

\section{DISCUSSION}

Interpretation of the Dauki fault as an overthrust is consistent with Molnar's (1987) interpretation of the seismotectonics of the region. Geologic data presented here allow its history as a thrust fault to be extended to the Early Pliocene, and provide the basis for crude estimates of the amount of overthrusting. The Shillong Plateau subsided more slowly than the Sylhet trough during the Cretaceous to Miocene, having a composite section for this interval of about $5000 \mathrm{~m}$ (fig. 4) and a maximum preserved section in any one place of only about $3000 \mathrm{~m}$ (Chakraborty, 1972). Thus, to uplift the basement of the Shillong Plateau to its present maximum elevation of about two kilometers, about $5-7 \mathrm{~km}$ of vertical displacement is required. This contrasts with the $18 \mathrm{~km}$ of vertical uplift proposed by Hiller and Elahi (1984) based on matching the submerged basement of the Sylhet trough with the elevated Shillong Plateau basement. Molnar (1984, his fig. 1) and Ni and Barazangi (1984, their fig. 14) show dips of about $5^{\circ}$ to $10^{\circ}$ for the Main Boundary thrust fault in the Himalayas (fig. 1). If the Dauki fault (which has a straight trace over an essentially flat surface) has a similar $5^{\circ}-10^{\circ}$ dip or shallows rapidly to a similar dip, then the amount of overthrusting required to produce the minimum 5-7 kms of vertical displacement ranges from $28 \mathrm{~km}$ ( $10^{\circ}$ dip, $5 \mathrm{~km}$ of vertical uplift) to $80 \mathrm{~km}$ ( $5^{\circ} \mathrm{dip}, 7 \mathrm{~km}$ of vertical uplift). Shallower or steeper dips on the inferred Dauki thrust fault at depth would require more or less horizontal displacement, respectively. Increased thickness estimates for the amount of sedimentary cover eroded from the Shillong Plateau would also increase the estimates of both vertical uplift and horizontal transport. This rough estimate of a few tens of $\mathrm{km}$ of Pliocene to Holocene horizontal tectonic transport provides a mechanism for some of the facies and(or) thickness changes in Mesozoic and Cenozoic strata between the Shillong Plateau and the adjacent Sylhet trough and Naga Hills (fig. 4; Evans, 1964).

Accepting the crude estimates of offset above, inferred rates of horizontal displacement on the Dauki fault range from 5.6 to $16 \mathrm{~mm} / \mathrm{year}$ ( 28 to $80 \mathrm{~km}$ over 5 million 
years). The present rate of convergence between the Indian and Eurasian plates is about 50 $\mathrm{mm} /$ year, but Molnar (1984) estimates that only $10-25 \mathrm{~mm} /$ year of this amount is accomodated across the Himalaya. Thus, a significant proportion of the convergence in the eastern Himalayas over the last five million years may have been taken up on the Dauki fault. Overthrusting on the Dauki fault may have an oblique (dextral) component, as suggested by the northeastward deflection of Pliocene-Pleistocene folds in the Sylhet trough (fig. 2)

The Main Boundary thrust fault, the present frontal thrust of the Himalayas, was also initiated in the Pliocene. It therefore seems likely that, since the Pliocene, convergence in this area has been partitioned between thrust faulting below both the Himalayas and the Shillong Plateau. It follows that the rate of underthrusting of the Brahmaputra valley just north of the Shillong Plateau beneath the Himalayas is less than that of the Indian Shield beneath the Himalayas west of the plateau (Molnar, 1987). A significant discontinuity having right-lateral displacement might therefore occur on the western margin of the Shillong Plateau, where the styles of convergence change. The course of the Jamuna River (the main distributary of the Brahmaputra) now follows a major north-trending lineament in this region which is characterized by recent faulting (Morgan and McIntire, 1959; Coleman, 1969 ; D.A. Coates, personal commun., 1989). Alternatively, the amount of offset on the Dauki fault may diminish to the west (implying clockwise rotation of the Shillong Plateau around a pivot point near its southwest border), as suggested by 1) the decreased thickness of the Tipam Sandstone-Dupi Tila Formation interval in the western, flat-lying part of Sylhet trough (suggesting less crustal loading to the west), and 2) the increased thickness of sedimentary cover on the Shillong Plateau at its west end (Chakraborty, 1972), suggesting decreased vertical uplift in that area. If offset on the Dauki fault does decrease to the west, then the magnitude of the suggested discontinuity at the west end of the Shillong Plateau would be diminished.

Burbank and Raynolds (1988) described a synchronous partitioning of convergence between the Main Boundary thrust fault and the Salt Range thrust, and significant rotation in thrust sheets, in the vicinity of the Northwest syntaxis at the west end of the Himalayas in Pakistan. This style of deformation has not been reported along the linear $(\sim 1800-\mathrm{km}-$ long) front of the main part of the Himalayas, and therefore may be a general characteristic of compressional deformation in syntaxial areas.

Finally, it is emphasized that, if our model for Pliocene to Holocene overthrusting of the Shillong Plateau is correct, this deformation occurred simultaneously with IndoBurman ranges folding in the Sylhet trough. These two compressive deformations, with nearly perpendicular trends, are occurring at the same upper crustal level. The IndoBurman ranges fold belt is being depressed by the Shillong Plateau into a foreland basin.

\section{CONCLUSIONS}

The pre-Oligocene history of the Bengal Basin was characterized by sedimentation on a passive continental margin associated with Mesozoic rifting and opening of the Indian Ocean. The Sylhet trough likely occupied a transitional setting on this margin between shelf deposits to the northwest, and basinal deposits to the southeast. Subsidence rates may have increased slightly during the Oligocene as a response to crustal loading from the developing Indo-Burman ranges. Oligocene strata (Barail Formation) on the northern (probably allochthonous) margin of the Sylhet trough are fluvial, but probably pass rapidly to the southeast into delta and prodelta deposits of a more rapidly subsiding trough on the west flank of the Indo-Burman ranges. Barail Formation sediments were probably derived from northern sources during incipient Himalayan uplift.

Subsidence rates accelerated in the Miocene, mainly in response to encroachment of the frontal zone of the Indo-Burman ranges. Miocene strata of the Surma Group were 
predominantly deposited in a large river-, wave- and tide(?)-influenced delta system that drained a large proportion of the emerging, eastern Himalayas.

Subsidence rates increased dramatically from the Miocene to the Pliocene in the Sylhet trough. The transition from the Surma Group to the Tipam Sandstone is marked by a major facies from prodelta to braided-river deposits, and petrologic changes. These changes are attributed primarily to the effects of south-directed overthrusting of the Shillong Plateau on the Dauki fault for the following reasons: 1) Pliocene and Pleistocene strata thin markedly away from the Shillong Plateau, consistent with a crustal load emplaced on the northern basin margin. 2) The largest component of this crustal load could not have been driven by either the Indo-Burman ranges, because the Sylhet trough was in the frontal deformation zone of this orogenic belt during this time, or the Himalayas, which were too remote. 3) South-directed overthrusting of the Shillong Plateau is consistent with gravity data and with recent seismotectonic observations (Seeber and Armbruster, 1981; Molnar, 1987). 4) Pliocene rocks are not represented on the Shillong Plateau, suggesting this massif was an emergent block at this time. If the Dauki fault (a high angle fault at the surface) were to shallow at depth to a dip similar to that of other major Himalayan overthrusts (about 5 to $10^{\circ}$ ), then a few tens of $\mathrm{km}$ of horizontal tectonic transport would be required to carry the Shillong Plateau to its present elevation.

\section{ACKNOWLEDGMENTS}

This research was conducted as a part of the Geological Survey of Bangladesh project "Accelerated exploration for mineral resources and modernization of the Geological Survey of Bangladesh," funded by the Asian Development Bank. We gratefully acknowledge the research and logistical support provided by S.K.M. Abdullah, Director General of the Geological Survey of Bangladesh, M.R. Khan, M.D. Kleinkopf, M. J. Terman, and J.W. Whitney. We thank the Bangladesh Oil, Gas, and Minerals Corporation (BOGMC) for permission to describe and sample core, to examine and reproduce seismic data and well logs, and for accommodations at Barlehka and Sylhet. We were helped in the field by A. Akhter, M. Ali, E.M. Brouwers, S.M. Hossain, M.R. Khan, N. Uddin, and the Bangladesh Rifles (national border guard). We benefitted from the technical help of $V$. F. Nuccio, and from stimulating discussions with D.W. Burbank, M. Ismail, P. Molnar, W. J. Perry, Jr., C. J. Potter, and A.H.M. Shamsuddin. D. W. Burbank, A. C. Christiansen, T. D. Fouch, K. J. Franczyk, E. A. Johnson, and J. C. Yount provided helpful reviews. Published with the approval of the Geological Survey of Bangladesh. 


\section{REFERENCES}

Acharya, S.K., Mitra, N.D., and Nandy, D.R., 1986, Regional geology and tectonic setting of northeast India and adjoining region, in Geology of Nagaland ophiolite: Geological Survey of India Memoirs, v. 119, p. 6-12.

Admiralty Tide Tables, 1984, Atlantic and Indian Oceans including tidal stream tables: Somerset, The Hydrographer of the Navy, v. 2.

Baksi, S.K., 1965, Stratigraphy of Barail Series in southern part of Shillong Plateau, Assam, India: American Association of Petroleum Geologists Bulletin, v. 49, p. 22822294.

Banerji, R.K., 1981, Cretaceous-Eocene sedimentation, tectonism, and biofacies in the Bengal Basin, India: Paleogeography, Paleoclimatology, and Paleoecology, v. 34, p. 57-85.

1984, Post-Eocene biofacies, paleoenvironments, and paleogeography of the Bengal Basin, India: Paleogeography, Paleoclimatology, and Paleoecology, v. 45, p. 49-73.

Brunnschweiler, R.O., 1966, On the geology of the Indo-Burman ranges (Arakan coast and Yoma, Chin Hills, Naga Hills): Geological Society of Australia Journal, v. 13, p. 137-194.

Brunnschweiler, R.O., and Khan, M.A.M., 1978, With Sherlock Holmes in the Bengal Basin: Singapore, Second Offshore Southeast Asia Conference, 5 p.

Burbank, D.W., and Raynolds, R.G.H., 1988, Stratigraphic keys to the timing of thrusting in terrestrial foreland basins - Applications to the northwestern Himalaya, in Kleinspehn, K.L., and Paola, C., eds., New perspectives in basin analysis: New York, Springer Verlag, p. 331-352.

Chakraborty, A., 1972, On the rock stratigraphy and tectonics of the sedimentary belt in the southwest of the Shillong Plateau, Meghalaya: Oil and Natural Gas Commission (India) Bulletin, v. 9, p. 133-141.

Chen, W.P., and Molnar, Peter, in press, Source parameters of earthquakes beneath the Shillong Plateau and the northern Indo-Burman ranges: Journal of Geophysical Research.

Coleman, J.M., 1969, Brahmaputra River - channel processes and sedimentation: Sedimentary Geology, v. 3, p. 129-239.

Curray, J.R., Emmel, F.J., Moore, D.G., and Raitt, R.W., 1983, Structure, tectonics, and geological history of the northeastern Indian Ocean, in Nairn, A.E.M., and Stelhi, F.G., eds., The ocean basins and margins, v. 6, The Indian Ocean: New York, Plenum, p. $399-450$.

Curray, J.R., and Moore, D.G., 1974, Sedimentary and tectonic processes in the Bengal deep sea fan and geosyncline, in Burke, C.A., and Drake, C.L., eds., The geology of continental margins: New York, Springer-Verlag, p. 617-628. 
Curtis, D. M., 1970, Miocene deltaic sedimentation, Louisiana gulf coast, in Morgan, J. P., ed., Deltaic sedimentation: Society of Economic Paleontologists and Mineralogists, Special Publication 15, p. 293-308.

Dasgupta, A.B., 1977, Geology of Assam Arakam region: Mining and Metallurgy Society India of India Quarterly Journal, v. 49, p. 1-54.

Desikachar, S.V., 1974, A review of the tectonic and geologic history of Eastern India in terms of plate tectonics theory: Geological Society of India Journal, v. 15, p. 137-149.

De Raaf, J.F.M., Boersma, J.R., and Van Gelder, A., 1977, Wave-generated structures and sequences from a shallow marine succession, Lower Carboniferous, County Cork, Ireland: Sedimentology, v. 24, p. 451-483.

Dickinson, W.R., 1985, Interpreting provenance relations from detrital modes of sandstones, in Zuffa, G.G., ed., Reading provenance from arenites: Riedel, p. 333361.

Evans, P., 1964, The tectonic framework of Assam: Geological Society of India Journal, v. 5 , p. $80-96$.

Gannser, A., 1964, Geology of the Himalaya: New York, Interscience, 289 p.

Gupta, V.J., 1976, Indian Cenozoic stratigraphy: Hindustan, Delhi, 344 p.

Hiller, K., and Elahi, M., 1984, Structural development and hydrocarbon entrapment in the Surma Basin, Bangladesh (northwest Indo-Burman fold belt): Singapore, Fifth Offshore Southeast Conference, p. 6-50-6-63.

Holtrop, J.F., and Keizer, J., 1970, Some aspects of the stratigraphy and correlation of the Surma Basin wells, East Pakistan: ESCAFE Mineral Resources Development Series no. 36 , p. $143-154$.

Imam, M.B., and Shaw, H.F., 1985, The diagenesis of Neogene clastic sediments from the Bengal Basin, Bangladesh: Journal of Sedimentary Petrology, v. 55, p. 665-671.

Ingersoll, R.V., Bullard, T.F., Ford, R.L., Grimm, J.P., Pickle, J.D., and Sares, S.W., 1984, The effect of grain size on detrital modes -- A test of the Gazzi-Dickinson pointcounting method: Journal of Sedimentary Petrology, v. 54, p. 103-116.

Khan, M.A.M., 1978, Geology of the eastern and the northeastern part of Sadar subdivision, Sylhet District, Bangladesh: Geological Survey of Bangladesh Records, v. $2,20 \mathrm{p}$.

Khan, M.A.M., Ismail, M., and Ahmad, M., 1988, Geology and hydrocarbon prospects of the Surma Basin, Bangladesh: Singapore, Seventh Offshore Southeast Asia Conference, p. 364-387.

Kuehl, S.A., Hariu, T.M., and Moore, W.S., 1989, Shelf sedimentation off the GangesBrahmaputra river system - Evidence for sediment bypassing to the Bengal fan: Geology, v. 17, p. 1132-1135.

LeDain, A.Y., Tapponier, Paul, and Molnar, Peter, 1984, Active faulting and tectonics of Burma and surrounding regions: Journal of Geophysical Research, v. 89, p. 453-472. 
LeFort, P., 1975, Himalayas -- The collided range -- Present knowledge of the continental arc: American Journal of Science, v. 275-A, p. 1-44.

Lietz, J.K., and Kabir, J., 1982, Prospects and constraints of oil exploration in Bangladesh: Singapore, Fourth Offshore Southeast Conference, p. 1-6.

Mitchell, A.H.G., and Reading, H.G., 1986, Sedimentation and tectonics, in Reading, H.G., ed., Sedimentary environments and facies: Oxford, Blackwell Scientific Publications, p.471-519.

Molnar, Peter, 1984, Structure and tectonics of the Himalaya--Constraints and implications of geophysical data: Earth and Planetary Sciences Annual Reviews, v. 12, p. 489-518.

1987, The distribution of intensity associated with the great 1897 Assam earthquake and bounds on the extent of the rupture zone: Geological Society of India Journal, v. 30 , p. 13-27.

Morgan, J.P., and McIntire, W.G., 1959, Quaternary geology of the Bengal Basin, East Pakistan and India: Geological Society of America Bulletin, v. 70, p. 319-342.

Murthy, M.V.N., Chakrabarti, C., and Talukdar, S.C., 1976, Stratigraphic revision of the Cretaceous-Tertiary sediments of the Shillong Plateau: Geological Survey of India Records, v. 107, p. $80-90$.

Murty, K.N., 1983, Geology and hydrocarbon prospects of Assam shelf -- Recent advances and present status: Petroleum Asia Journal, v. 6, p. 1-14.

Nandy, D.R., 1986, Tectonics, seismicity, and gravity of northeastern India and adjoining region, in Geology of Nagaland ophiolite: Geological Survey of India Memoirs, v. 119 , p. 13-17.

Ni, J.F., Guzman-Speciale, M., Holt, W.E., Wallace, T.C., and Seager, W.R., 1989, Accrectionary tectonics of Burma and the three dimensional geometry of the Burma subduction zone: Geology, v. 17, p. 68-71.

Ni, J.F., and Barazangi, M., 1984, Seismotectonics of the Himalayan collision zone -geometry of the underthrusting Indian plate beneath the Himalaya: Journal of Geophysical Research, v. 89, p. 1147-1163.

Oldham, R.D., 1899, Report on the great earthquake of 12th June, 1987: Geological Survey of India Memoir, v. 29 [reprinted, 1981].

Palmer, A.R., 1983, The Decade of North American Geology 1983 geologic time scale: Geology, v. 11, p. 503-504.

Rahman, M.A., Mannan, M.A., Blank, H.R., Jr., Kleinkopf, M.D., and Mirchanikov, S.M., 1990 (in press), Bouguer gravity map of Bangladesh: Geological Survey of Bangladesh, scale $1: 1,000,000$.

Rangorao, A., 1983, Geology and hydrocarbon potential of a part of Assam-Arakam basin and its adjacent region: Petroleum Asia Journal, v. 6, p. 127-158. 
Ray, D. K., 1982, Tectonic map of south and east Asia: Hyderabad (Geological Survey on India), Commission for the geological map of the world -- Subcommission for south and east Asia, 7 sheets, scale 1:5,000,000.

Salt, C.A., Alam, M.M., and Hossain, M.M., 1986, Bengal Basin - current exploration of the hinge zone of southwestern Bangladesh: Singapore, 6th Offshore Southeast Asia Conference, p. 55-67.

Sengupta, S., Ray, K.K., Acharya, S.K., and deSmeth, J.B., 1990, Nature of ophiolite occurrences along the esatern margin of the Indian plate and their tectonic significance: Geology, v. 18, p. 439-442.

Shrivastava, P.K., Ganeshan, S., and Rady, D., 1974, Tipam Group in the subsurface of upper Assam valley south of Brahmaputra: Geological Society of India Journal, v. 15, p. $165-181$.

Seeber, L., and and Armbruster, J., 1981, Great detachment earthquakes along the Himalayan arc and long-term forecasts, in Simpson, D.W., and Richards, P.G., eds., Earthquake prediction -- An international review, Maurice Ewing Series 4: Washington D.C., American Geophysical Union, p. 259-277.

Van Hinte, J. E., 1978, Geohistory analysis - Application of micropaleontology in exploration geology: American Association of Petroleum Geologists Bulletin, v. 62, p. 202-222.

Verna, R.K., and Krishna Kumar, G.V.R., 1987, Seismicity and the nature of plate movement along the Himalayan arc, northeast India and Arakan-Yoma -- A review: Tectonophysics, v. 134, p. 153-175.

Watts, A.B., and Steckler, M.S., 1979, Subsidence and eustacy at the continental margin of eastern North America: Washington D.C., American Geophyscial Union, Maurice Ewing Series, v. 3, p. 218-234.

Williams, G.E., 1989, Late Precambrian tidal rhythmites in South Australia and the history of the Earth's rotation: Geological Society of London Journal, v. 146, p. 97-111.

Wright, L.D., Wiseman, W.J., Bornhold, B.D., Prior, D.B., Suhayda, J.N., Keller, G.H., Yang, Z.S., and Fan, Y.B., 1988, Marine dispersal and deposition of Yellow River silts by gravity-driven underflows: Nature, v. 332, p.629-632. 


\begin{abstract}
APPENDIX
Raw petrographic data on point counts of 44 fine- to medium-grained sandstones or sands are presented below. Point counts were conducted using the Gazzi-Dickinson method (Ingersoll and others, 1984). All thin sections were stained for potassium feldspar. Due to surface weathering, the proportions of porosity and cements determined for surface samples may not be representative of the same units in the subsurface. Petrographic data are plotted in figures 5-7 and summarized in table 1.
\end{abstract}

Codes for tables of petrographic data.

1. Formation: $\mathrm{B}=$ Barail Formation; $\mathrm{D}=$ Dupi Tila Formation; $\mathrm{K}=$ Kopili Formation; $\mathrm{MD}=$ modern sand, Dauki River, $\mathrm{MH}=$ modern sand, Hari River, $\mathrm{S}=$ Surma Group; $\mathrm{T}=$ Tipam Sandstone.

2. Localities: $D=$ Dauki River, $F=$ Fenchuganj core (approximate depth); $H=$ Hari River, $\mathrm{J}=$ Jaintiapur area; $\mathrm{K}$ = Kailas Tila core (approximate depth); $\mathrm{L}=$ Lonely Chara; $\mathrm{M}=$ Muchhegul; MW = Madhabkund waterfall; T = Tama Bil area. Localities are shown in figure 2. The Lonely Chara, Muchhegul, and Madhabkund localities are on the west flank of the Patharia anticline.

3. Thin section: $1=$ standard thin section of surface outcrop; $2=$ standard thin section of core sample; 3 = grain mount.

4. Number of points counted.

5. Number of framework grains counted.

6-22. Modal percent of composition (not normalized to $100.0 \%$ ).

6. Monocrystalline quartz.

7. Foliated polycrystalline quartz.

8. Undifferentiated polycrystalline quartz.

9. Chert.

10. Plagioclase feldspar.

11. Potassium feldspar.

12. Sedimentary rock fragment.

13. Volcanic rock fragment.

14. Quartz-mica tectonite rock fragment.

15. Low-grade metamorphic rock fragment.

16. Biotite, muscovite, and chlorite.

17. Epidote, amphibole, and pyroxene. 
18. Opaque minerals, garnet, sphene, and other heavy minerals.

19. Matrix.

20. Calcite cement.

21. Hematite cement/matrix.

22. Porosity.

23. Plagioclase/total feldspar.

24. QFL (total quartz, feldspar, lithic fragments).

25. QmFLt (monocrystalline quartz, feldspar, lithic fragments).

26. QmPK (monocrystalline quartz, feldspar, lithic fragments).

For calculating Ternary ratios QFL, QmFLt, and QmPK:

$\mathrm{Q}=6+7+8+9 ; \mathrm{Qm}=6 ; \mathrm{F}=10+11 ; \mathrm{L}=12+13+14+15 ; \mathrm{Lt}=7+8+9+12+13$ $+14+15$. 
TABLE 2 (Page 1). PETROGRAPHIC DATA FOR SYLHET TROUGH SANDSTONES

\begin{tabular}{|c|c|c|c|c|c|}
\hline $\begin{array}{l}\text { SAMPLE } \\
\text { NUMBER }\end{array}$ & SJ-89-B22 & SJ-89-B15 & SJ-89-B 17 & SJ-89-B53 & SJ-89-B54 \\
\hline \multicolumn{6}{|l|}{ Code } \\
\hline 1 & $\mathrm{~K}$ & B & B & B & B \\
\hline 2 & D & $\mathrm{T}$ & $\mathrm{T}$ & J & $\mathrm{J}$ \\
\hline 3 & 1 & 1 & 1 & 1 & 1 \\
\hline 4 & 489 & 475 & 472 & 650 & 597 \\
\hline 5 & 312 & 307 & 373 & 332 & 341 \\
\hline 6 & 45.6 & 51.1 & 52.8 & 43.2 & 37.0 \\
\hline 7 & & 0.2 & 0.8 & & \\
\hline 8 & 3.3 & 2.5 & 2.1 & 2.6 & 2.7 \\
\hline 9 & 3.9 & 1.1 & 0.6 & 0.2 & 1.5 \\
\hline 10 & 6.5 & 1.5 & 7.8 & 1.8 & 2.7 \\
\hline 11 & 1.2 & 3.2 & 1.7 & 0.6 & 3.3 \\
\hline 12 & 2.7 & 1.5 & 4.2 & 2.3 & 9.6 \\
\hline 13 & & 0.2 & 6.1 & & \\
\hline 14 & 0.6 & 1.2 & 2.8 & 0.3 & 0.3 \\
\hline 15 & & 3.2 & & & \\
\hline 16 & 6.2 & 8.4 & 3.4 & 0.9 & 22.9 \\
\hline 17 & 0.8 & 0.2 & 0.4 & 0.2 & 0.3 \\
\hline 18 & 1.4 & 0.6 & 0.8 & & 0.5 \\
\hline 19 & 3.7 & & & & \\
\hline & & & & & \\
\hline 21 & & & & 44.4 & \\
\hline 22 & 24.1 & 25.1 & 16.3 & 3.4 & 19.1 \\
\hline 23 & 0.84 & 0.32 & 0.82 & 0.75 & 0.44 \\
\hline 24 & $83,12,5$ & $83,7,10$ & $71,12,17$ & $90,5,5$ & $72,11,17$ \\
\hline 25 & $71,12,17$ & $79,7,14$ & $67,12,21$ & $85,5,10$ & $65,11,24$ \\
\hline 26 & $85,12,3$ & $92,3,5$ & $85,12,3$ & $95,4,1$ & $87,6,7$ \\
\hline
\end{tabular}


TABLE 2 (Page 2). PETROGRAPHIC DATA FOR SYLHET TROUGH SANDSTONES

\begin{tabular}{|c|c|c|c|c|c|}
\hline $\begin{array}{l}\text { SAMPLE } \\
\text { NUMBER }\end{array}$ & SJ-89-B61 & SJ-89-B62 & SJ-89-B64 & SJ-89-B65 & SJ-89-B11 \\
\hline $\begin{array}{l}\text { Code } \\
1 \\
2 \\
3 \\
4 \\
5\end{array}$ & $\begin{array}{r}\mathrm{B} \\
\mathrm{T} \\
1 \\
482 \\
330\end{array}$ & $\begin{array}{c}\mathrm{B} \\
\mathrm{T} \\
1 \\
410 \\
314\end{array}$ & $\begin{array}{c}\mathrm{B} \\
\mathrm{T} \\
1 \\
379 \\
315\end{array}$ & $\begin{array}{c}\text { B } \\
\mathrm{T} \\
1 \\
426 \\
309\end{array}$ & $\begin{array}{l}\mathrm{S} \\
\mathrm{Mw} \\
1 \\
583 \\
338\end{array}$ \\
\hline $\begin{array}{l}6 \\
7\end{array}$ & 50.4 & 64.6 & 64.1 & 51.6 & 39.8 \\
\hline $\begin{array}{c}8 \\
9 \\
10\end{array}$ & $\begin{array}{l}6.2 \\
0.6 \\
2.9\end{array}$ & $\begin{array}{l}0.2 \\
2.7\end{array}$ & $\begin{array}{l}0.5 \\
2.1 \\
1.1\end{array}$ & $\begin{array}{l}3.3 \\
0.5 \\
2.6\end{array}$ & $\begin{array}{l}3.3 \\
0.3 \\
4.1\end{array}$ \\
\hline $\begin{array}{l}11 \\
12 \\
13 \\
14 \\
15\end{array}$ & $\begin{array}{l}0.4 \\
4.4 \\
\\
2.1 \\
1.5\end{array}$ & $\begin{array}{l}2.0 \\
5.1 \\
2.2\end{array}$ & $\begin{array}{r}1.1 \\
10.0 \\
4.2\end{array}$ & $\begin{array}{l}2.1 \\
7.0 \\
5.4\end{array}$ & $\begin{array}{l}7.2 \\
1.9 \\
0.3 \\
1.0\end{array}$ \\
\hline $\begin{array}{l}16 \\
17 \\
18 \\
19 \\
20\end{array}$ & $\begin{array}{l}1.6 \\
1.0\end{array}$ & $\begin{array}{l}1.7 \\
0.4\end{array}$ & 0.3 & $\begin{array}{l}1.0 \\
0.2\end{array}$ & $\begin{array}{r}20.9 \\
0.2 \\
2.4 \\
0.3 \\
17.3\end{array}$ \\
\hline $\begin{array}{l}21 \\
22 \\
23 \\
24 \\
25\end{array}$ & $\begin{array}{c}13.3 \\
15.6 \\
0.88 \\
84,4,12 \\
74,4,22\end{array}$ & $\begin{array}{c}13.4 \\
7.6 \\
0.58 \\
84,6,10 \\
84,6,10\end{array}$ & $\begin{array}{c}3.2 \\
13.5 \\
0.50 \\
80,3,17 \\
77,3,20\end{array}$ & $\begin{array}{c}12.9 \\
13.4 \\
0.55 \\
76,7,17 \\
71,7,22\end{array}$ & $\begin{array}{c}0.9 \\
0.36 \\
75,20,5 \\
69,20,11\end{array}$ \\
\hline 26 & $94,5,1$ & $93,4,3$ & $97,1,1$ & $91,5,4$ & $78,8,14$ \\
\hline
\end{tabular}


TABLE 2 (Page 3). PETROGRAPHIC DATA FOR SYLHET TROUGH SANDSTONES

\begin{tabular}{|c|c|c|c|c|c|}
\hline $\begin{array}{l}\text { SAMPLE } \\
\text { NUMBER }\end{array}$ & SJ-89-B49 & SJ-89-B68 & SJ-89-B69 & $\mathrm{SJ}-89-\mathrm{B} 73$ & SJ-89-B76 \\
\hline $\begin{array}{l}\text { Code } \\
1 \\
2 \\
3 \\
4 \\
5\end{array}$ & $\begin{array}{c}S \\
H \\
1 \\
571 \\
358\end{array}$ & $\begin{array}{c}S \\
J \\
1 \\
512 \\
291\end{array}$ & $\begin{array}{c}S \\
J \\
1 \\
358 \\
302\end{array}$ & $\begin{array}{c}\mathrm{S} \\
\mathrm{K}(\underset{2965 \mathrm{~m})}{2} \\
438 \\
339\end{array}$ & $\begin{array}{c}\mathrm{S} \\
\mathrm{K}(\sim 2300 \mathrm{~m}) \\
3 \\
326 \\
311\end{array}$ \\
\hline $\begin{array}{c}6 \\
7 \\
8 \\
9 \\
10\end{array}$ & $\begin{array}{l}40.1 \\
\\
2.5 \\
1.4 \\
6.8\end{array}$ & $\begin{array}{l}39.5 \\
\\
0.4 \\
4.3\end{array}$ & $\begin{array}{r}70.1 \\
\\
0.6 \\
0.3 \\
5.0\end{array}$ & $\begin{array}{r}48.2 \\
0.2 \\
3.7 \\
1.6 \\
3.7\end{array}$ & $\begin{array}{r}60.5 \\
3.1 \\
0.6 \\
0.3 \\
6.4\end{array}$ \\
\hline $\begin{array}{l}11 \\
12 \\
13 \\
14 \\
15\end{array}$ & $\begin{array}{l}7.4 \\
2.8 \\
\\
0.3\end{array}$ & $\begin{array}{l}5.3 \\
5.5 \\
0.2 \\
1.8\end{array}$ & $\begin{array}{l}3.1 \\
5.9 \\
0.3\end{array}$ & $\begin{array}{l}8.2 \\
8.7 \\
1.4 \\
1.8\end{array}$ & $\begin{array}{r}11.3 \\
10.4 \\
1.2 \\
1.5\end{array}$ \\
\hline $\begin{array}{l}16 \\
17 \\
18 \\
19 \\
20\end{array}$ & $\begin{array}{l}19.6 \\
1.8 \\
15.9\end{array}$ & $\begin{array}{l}5.7 \\
0.4\end{array}$ & $\begin{array}{r}11.8 \\
0.6 \\
2.2\end{array}$ & $\begin{array}{l}1.1 \\
0.7 \\
0.2\end{array}$ & $\begin{array}{l}2.4 \\
0.6 \\
1.5\end{array}$ \\
\hline $\begin{array}{l}21 \\
22 \\
23 \\
24 \\
25\end{array}$ & $\begin{array}{c}1.4 \\
0.48 \\
70,23,7 \\
64,23,13\end{array}$ & $\begin{array}{c}11.7 \\
25.4 \\
0.45 \\
70,17,13 \\
69,17,14\end{array}$ & $\begin{array}{c}0.3 \\
0.62 \\
84,9,7 \\
83,9,8\end{array}$ & $\begin{array}{c}20.5 \\
0.31 \\
69,15,16 \\
62,15,22\end{array}$ & $\begin{array}{c}0.36 \\
67,19,14 \\
63,19,18\end{array}$ \\
\hline 26 & $75,12,13$ & $81,8,11$ & $90,6,4$ & $80,6,14$ & $77,8,15$ \\
\hline
\end{tabular}


TABLE 2 (Page 4). PETROGRAPHIC DATA FOR SYLHET TROUGH SANDSTONES

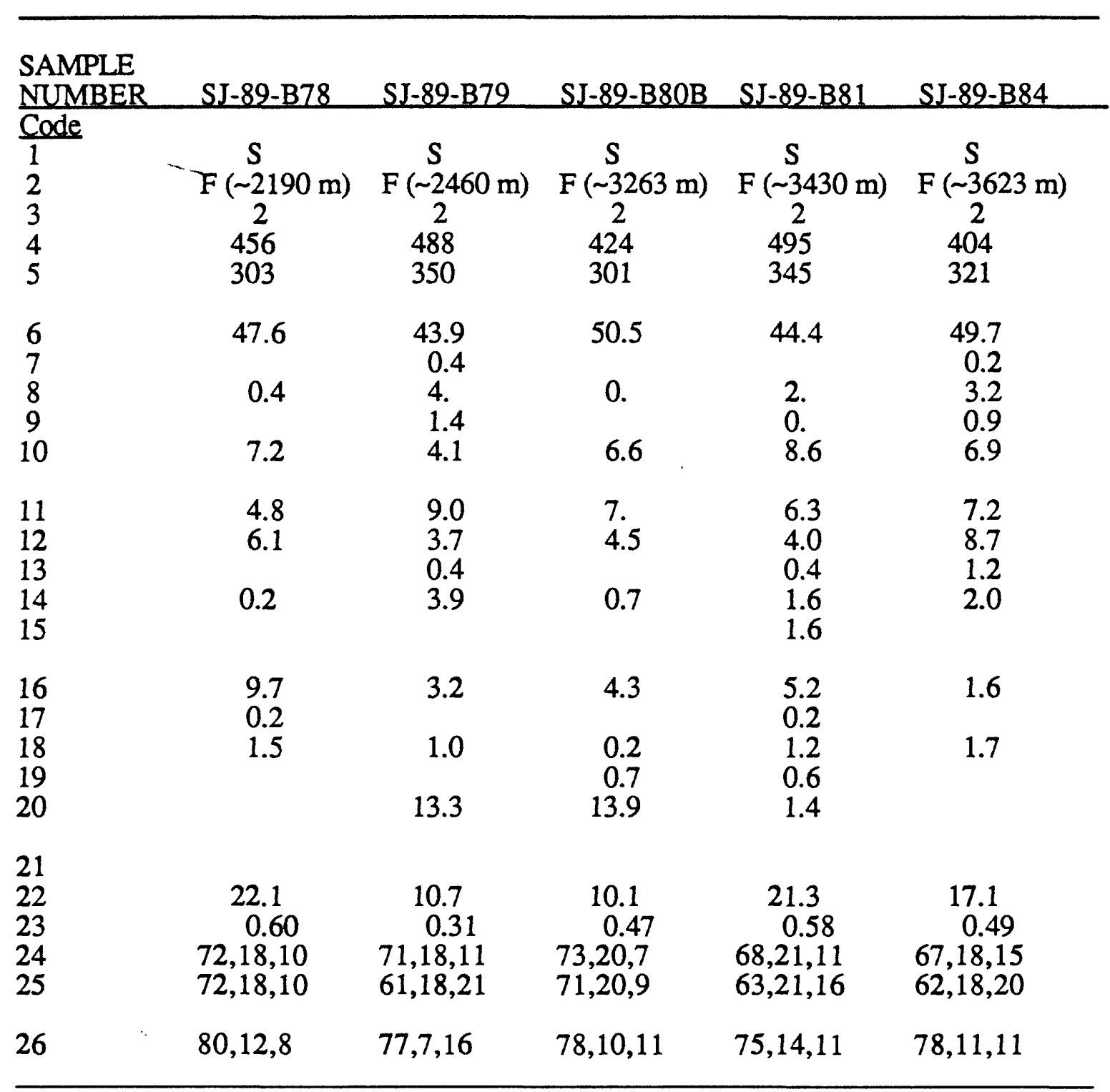


TABLE 2 (Page 5). PETROGRAPHIC DATA FOR SYLHET TROUGH SANDSTONES

\begin{tabular}{|c|c|c|c|c|c|}
\hline $\begin{array}{l}\text { SAMPLE } \\
\text { NUMBER }\end{array}$ & SJ-89-B85 & SJ-89-B86 & SJ-89-B89 & SJ-89-B4 & SJ-89-B5 \\
\hline $\begin{array}{l}\frac{\text { Code }}{1} \\
2 \\
3 \\
4 \\
5\end{array}$ & $\begin{array}{c}\mathrm{S} \\
\mathrm{F}(\sim 4090 \mathrm{~m}) \\
2 \\
367 \\
311\end{array}$ & $\begin{array}{c}\mathrm{S} \\
\mathrm{F}(\sim 4250 \mathrm{~m}) \\
2 \\
485 \\
350\end{array}$ & $\begin{array}{c}S \\
F(\sim 4425 \mathrm{~m}) \\
2 \\
484 \\
345\end{array}$ & $\begin{array}{c}\mathrm{T} \\
\mathrm{L}- \\
3 \\
334 \\
305\end{array}$ & $\begin{array}{c}\mathrm{T} \\
\mathrm{L} \\
1 \\
649 \\
377\end{array}$ \\
\hline $\begin{array}{c}6 \\
7 \\
8 \\
9 \\
10\end{array}$ & $\begin{array}{r}56.0 \\
\\
3.8 \\
0.5 \\
7.1\end{array}$ & $\begin{array}{r}38.8 \\
4.3 \\
0.4 \\
10.5\end{array}$ & $\begin{array}{l}44.2 \\
2.7 \\
0.2 \\
7.6\end{array}$ & $\begin{array}{r}57.5 \\
1.2 \\
6.6\end{array}$ & $\begin{array}{r}36.2 \\
0.5 \\
4.6 \\
1.4 \\
2.6\end{array}$ \\
\hline $\begin{array}{l}11 \\
12 \\
13 \\
14 \\
15\end{array}$ & $\begin{array}{l}7.7 \\
6.3 \\
1.4 \\
2.2\end{array}$ & $\begin{array}{l}8.5 \\
6.4 \\
3.3\end{array}$ & $\begin{array}{l}7.9 \\
6.6 \\
0.4 \\
1.2 \\
0.4\end{array}$ & $\begin{array}{r}10.8 \\
14.7 \\
0.6\end{array}$ & $\begin{array}{l}5.1 \\
5.2 \\
2.5\end{array}$ \\
\hline $\begin{array}{l}16 \\
17 \\
18 \\
19 \\
20\end{array}$ & $\begin{array}{l}6.3 \\
0.3 \\
\\
0.5 \\
8.1\end{array}$ & $\begin{array}{l}5.0 \\
0.4 \\
1.8\end{array}$ & $\begin{array}{r}10.1 \\
1.0 \\
0.2\end{array}$ & $\begin{array}{l}4.8 \\
2.7 \\
1.2\end{array}$ & $\begin{array}{r}22.9 \\
0.3 \\
0.4\end{array}$ \\
\hline $\begin{array}{l}21 \\
22 \\
23 \\
24 \\
25\end{array}$ & $\begin{array}{r}0.48 \\
71,17,12 \\
66,17,17\end{array}$ & $\begin{array}{c}20.5 \\
0.55 \\
60,26,14 \\
54,26,20\end{array}$ & $\begin{array}{c}16.9 \\
0.49 \\
66,22,12 \\
62,22,16\end{array}$ & $\begin{array}{c}0.38 \\
64,19,17 \\
63,19,18\end{array}$ & $\begin{array}{c}18.2 \\
0.34 \\
73,13,14 \\
62,13,24\end{array}$ \\
\hline 26 & $79,10,11$ & $67,18,15$ & $74,13,13$ & $77,9,14$ & $73,13,14$ \\
\hline
\end{tabular}


TABLE 2 (Page 6). PETROGRAPHIC DATA FOR SYLHET TROUGH SANDSTONES

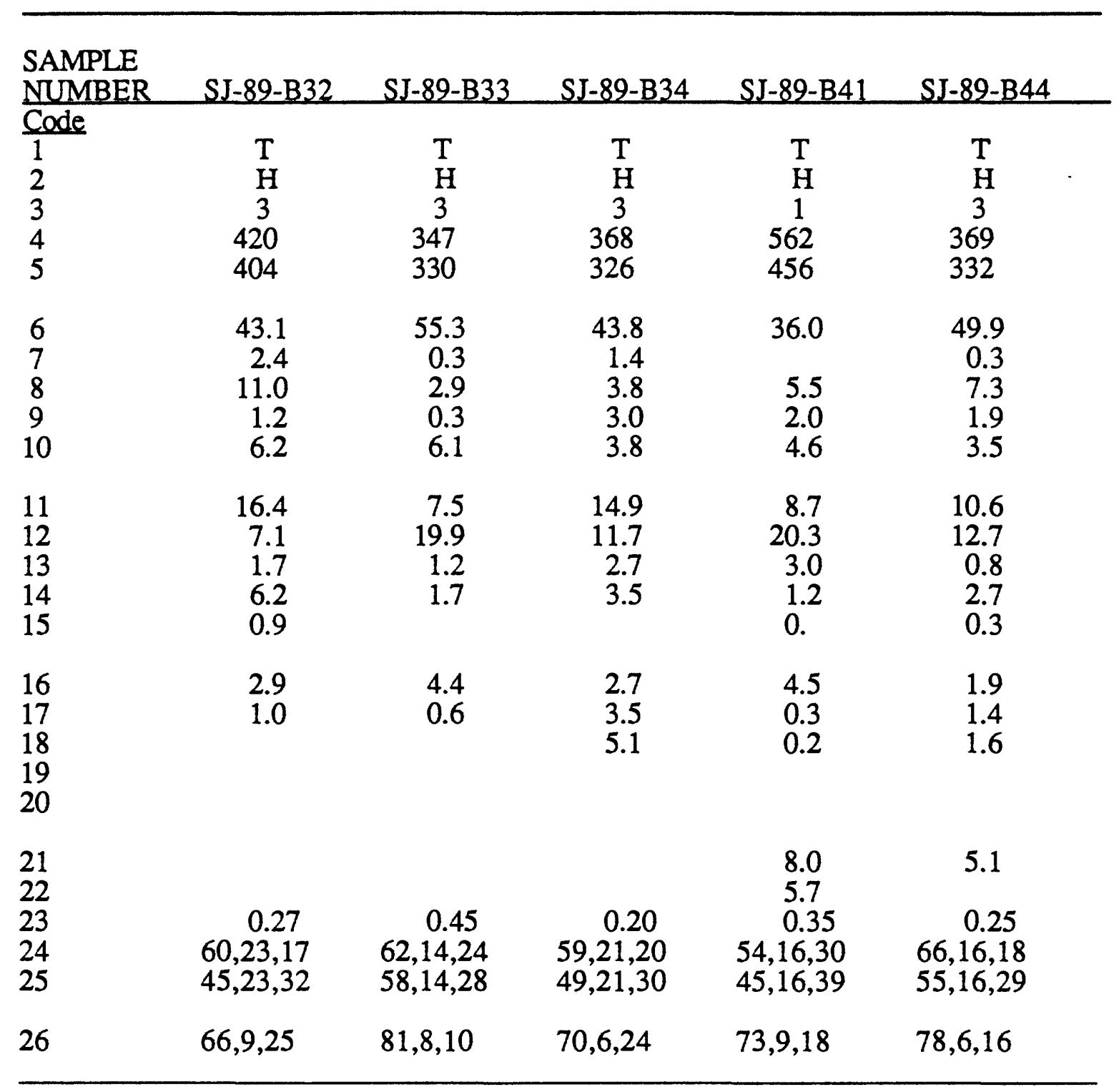


TABLE 2 (Page 7). PETROGRAPHIC DATA FOR SYLHET TROUGH SANDSTONES

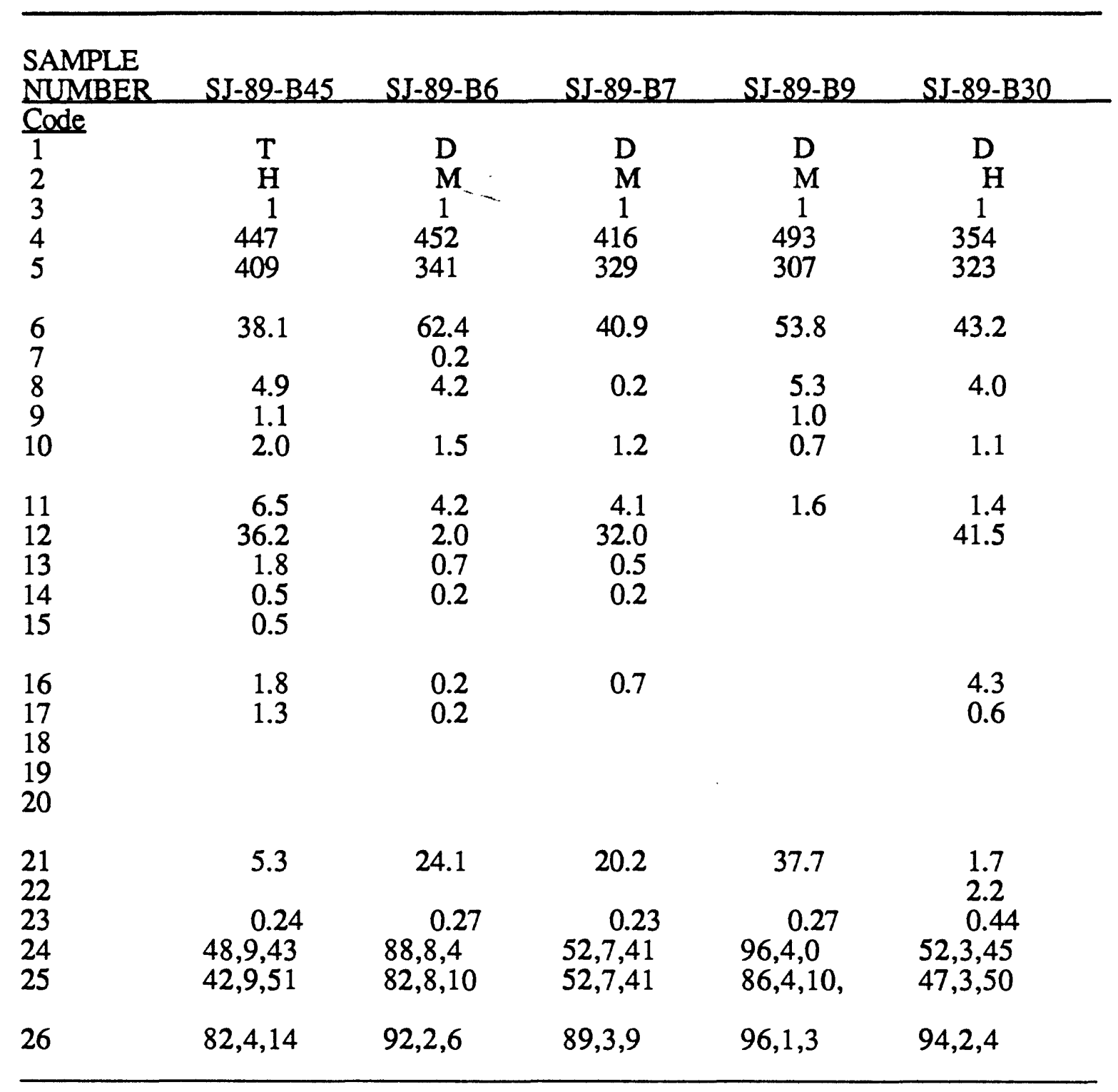


TABLE 2 (Page 8). PETROGRAPHIC DATA FOR SYLHET TROUGH SANDSTONES

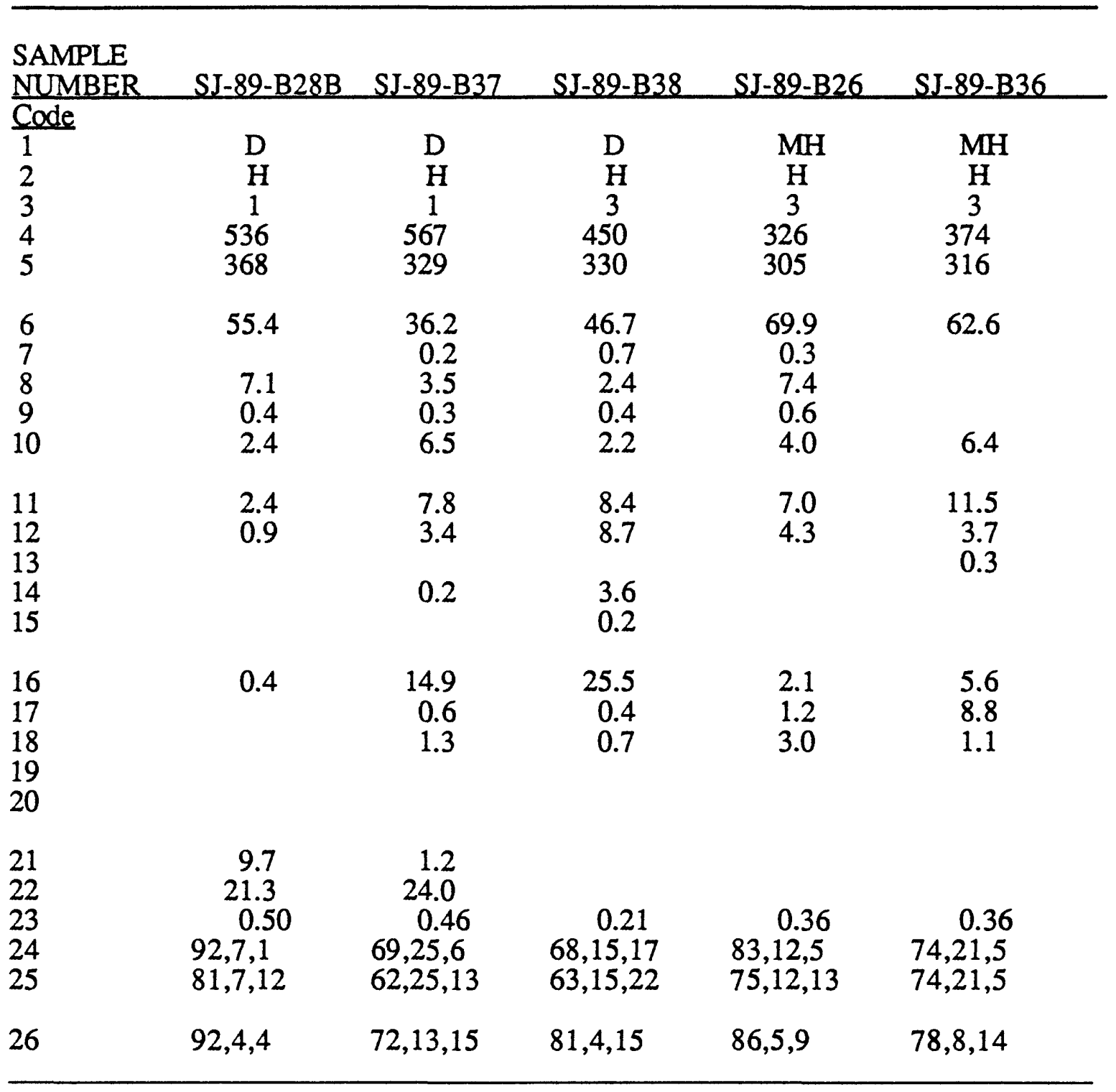


TABLE 2 (Page 9). PETROGRAPHIC DATA FOR SYLHET TROUGH SANDSTONES

\begin{tabular}{|c|c|c|c|c|}
\hline $\begin{array}{l}\text { SAMPLE } \\
\text { NUMBER }\end{array}$ & SJ-89-B 48 & SJ-89-B56 & SJ-89-B57 & SJ-89-B60 \\
\hline $\begin{array}{l}\text { Code } \\
1 \\
2 \\
3 \\
4 \\
5\end{array}$ & $\begin{array}{c}\text { MH } \\
\mathrm{H} \\
3 \\
336 \\
325\end{array}$ & $\begin{array}{c}\mathrm{MD} \\
\mathrm{D} \\
3 \\
430 \\
352\end{array}$ & $\begin{array}{c}\mathrm{MD} \\
\mathrm{D} \\
3 \\
441 \\
363\end{array}$ & $\begin{array}{c}\text { MD } \\
\text { D } \\
3 \\
318 \\
314\end{array}$ \\
\hline $\begin{array}{c}6 \\
7 \\
8 \\
9 \\
10\end{array}$ & $\begin{array}{r}68.1 \\
7.7 \\
0.3 \\
8.3\end{array}$ & $\begin{array}{r}47.2 \\
0.2 \\
0.7 \\
0.2 \\
10.5\end{array}$ & $\begin{array}{r}42.0 \\
1.4 \\
11.1\end{array}$ & $\begin{array}{r}60.7 \\
\\
0.9 \\
11.3\end{array}$ \\
\hline $\begin{array}{l}11 \\
12 \\
13 \\
14 \\
15\end{array}$ & $\begin{array}{l}9.5 \\
2.7\end{array}$ & $\begin{array}{r}19.5 \\
2.6 \\
0.5 \\
0.5\end{array}$ & $\begin{array}{r}19.7 \\
5.0 \\
1.1 \\
1.1 \\
0.9\end{array}$ & $\begin{array}{r}21.4 \\
4.4\end{array}$ \\
\hline $\begin{array}{l}16 \\
17 \\
18 \\
19 \\
20\end{array}$ & $\begin{array}{l}1.2 \\
1.4 \\
0.9\end{array}$ & $\begin{array}{l}7.2 \\
7.4 \\
3.5\end{array}$ & $\begin{array}{l}9.5 \\
6.1 \\
2.1\end{array}$ & $\begin{array}{l}0.9 \\
0.3\end{array}$ \\
\hline $\begin{array}{l}21 \\
22 \\
23 \\
24 \\
25\end{array}$ & $\begin{array}{c}0.47 \\
79,18,3 \\
70,18,12\end{array}$ & $\begin{array}{r}0.35 \\
59,37,4 \\
58,37,5\end{array}$ & $\begin{array}{c}0.36 \\
53,37,10 \\
51,37,12\end{array}$ & $\begin{array}{r}0.35 \\
62,33,5 \\
61,33,6\end{array}$ \\
\hline 26 & $79,10,11$ & $61,14,25$ & $58,15,27$ & $65,12,23$ \\
\hline
\end{tabular}

